\title{
Do Agglomeration Economies Reduce the Sensitivity of Firm Location to Tax Differentials?*
}

\author{
Marius Brülhart ${ }^{\dagger}$ \\ Mario Jametti ${ }^{\ddagger}$ \\ University of Lausanne \\ York University, Toronto \\ Kurt Schmidheiny ${ }^{\S}$ \\ Universitat Pompeu Fabra
}

December 2007

\begin{abstract}
Low corporate taxes can help attract new firms. This is the main mechanism underpinning the standard 'race-to-the-bottom' view of tax competition. A recent theoretical literature has qualified this view by formalizing the argument that agglomeration forces can reduce firms' sensitivity to tax differentials across locations. We test this proposition using data on firm startups across Swiss municipalities. We find that, on average, high corporate income taxes do deter new firms, but that this relationship is significantly weaker in the most spatially concentrated sectors. Location choices of firms in sectors with an agglomeration intensity at the twentieth percentile of the sample distribution are estimated to be twice as responsive to a given difference in local corporate tax burdens as firms in sectors with an agglomeration intensity at the eightieth percentile. Hence, our analysis confirms the theoretical prediction: agglomeration economies can neutralize the impact of tax differentials on firms' location choices.
\end{abstract}

JEL Classification: R3, H32

Keywords: firm location, agglomeration economies, local taxation, count models, Switzerland

$<$ All tables and figures at end $>$

\footnotetext{
${ }^{*}$ We thank Richard Baldwin, Antonio Ciccone, Gilles Duranton, Diego Puga, Albert Sole-Ollé, Dan Trefler, Federico Trionfetti, Jean-François Wen, and seminar participants at the Universities of Barcelona, Dijon (INRACESAER), Geneva (Graduate Institute of International Studies), the London School of Economics, Pompeu Fabra, St. Gallen, Toronto, Vienna (IHS), Warwick (IIPF) and York for helpful comments. Jean-François Fracheboud and Andrea Grossi at the Swiss Federal Statistical Office have generously facilitated our access to the data. Financial support from the Swiss National Science Foundation (grants 612-65970, PBLA1-106054 and PA001-105026), from the EU's Sixth Framework Program ("Micro-Dyn" project), from the Social Sciences and Humanities Research Council of Canada, and from the Barcelona Economics Program of CREA is gratefully acknowledged.

${ }^{\dagger}$ Corresponding author: Département d'économétrie et économie politique, Ecole des HEC, Université de Lausanne, CH - 1015 Lausanne, Switzerland. E-mail: Marius.Brulhart@unil.ch. Web page: www.hec.unil.ch/mbrulhar. Also affiliated with the Centre for Economic Policy Research.

${ }^{\ddagger}$ Department of Economics, York University, 4700 Keele St., Toronto, Ontario, M3J 1P3, Canada; e-mail: jametti@econ. yorku.ca.

${ }^{\S}$ Department of Economics and Business, Universitat Pompeu Fabra, Ramon Trias Fargas 25-27, 08005 Barcelona, Spain; e-mail: kurt.schmidheiny@upf.edu. Also affiliated with CESifo.
} 


\section{Introduction}

According to the standard model of tax competition, increasing mobility of firms induces a race to the bottom in corporate taxes. ${ }^{1}$ Recent theoretical work has fundamentally questioned the relevance of this scenario. In most 'new economic geography' models, the strength of geographical agglomeration forces increases as goods and factors become more mobile. As a result, somewhat paradoxically, the scope for attracting firms through fiscal inducements could in fact shrink as technological and administrative obstacles to firm mobility are reduced. The existence of agglomeration forces could thus allow governments to continue to tax corporate income even once capital has in principle become highly mobile.

We provide an empirical verification of the hypothesis that agglomeration forces can offset differences in corporate taxes as a determinant of firm location. Estimating location choice models for firm start-ups across Swiss municipalities, we find that high corporate taxes are indeed a deterrent to firm location, but that this deterrent effect is significantly weaker for sectors that are more spatially clustered. Hence, agglomeration economies - be they due to externalities or to spatially concentrated endowments - can reduce the ability (and incentive) of jurisdictions to compete for firms via strategically low tax rates.

These results are based on Poisson regressions derived from firm-level profit functions in a location choice model. We first estimate a 'baseline model' of firms' location choices, in which we introduce an explicit interaction term between municipal corporate taxes and a measure of sector-level agglomeration. In an alternative approach, we then estimate a 'specific model' that is formally derived from a model of spatial demand and supply conditions. In that model, the relative effect of taxes versus agglomeration forces features implicitly rather than via an explicit interaction term. We minimize simultaneity problems between taxes and firm location by using sector-level counts of new firms as the dependent variable, and municipal corporate taxes which apply identically to firms across all sectors as the independent variable. Unobserved sector characteristics are controlled for via fixed effects, and the qualitative results are shown to be robust across a range of specifications and at different levels of sectoral aggregation.

We proceed as follows. Section 2 provides a brief review of the relevant literature. Section 3 presents the two estimable models. Our empirical setting and data set are described in

\footnotetext{
${ }^{1}$ For a comprehensive review of this literature, see Wilson (1999).
} 
Section 4. Estimation results are reported in Section 5, and Section 6 concludes.

\section{$2 \quad$ Literature background}

The implications of agglomeration economies for strategic tax setting among jurisdictions competing for mobile tax bases have been studied in a number of theoretical contributions, including Ludema and Wooton (2000), Kind, Midelfart-Knarvik and Schjelderup (2000), Andersson and Forslid (2003), Baldwin and Krugman (2004), and Borck and Pflüger (2006). ${ }^{2}$ The key insight of this literature is that agglomeration forces make the world 'lumpy': when capital (or any other relevant production factor) is mobile and trade costs are sufficiently low, agglomeration forces lead to spatial concentrations of firms that cannot be dislodged with small tax inducements. ${ }^{3}$ In fact, agglomeration externalities create rents that can in principle be taxed by the jurisdiction that hosts the agglomeration. ${ }^{4}$

New economic geography models typically feature a single increasing-returns sector, the intensity of whose agglomeration forces varies (typically non-monotonically) with trade costs. Where agglomeration forces are strongest (i.e. at intermediate trade costs), the probability that the increasing-returns sector completely agglomerates in one region is highest, and the sensitivity to tax differentials is smallest. ${ }^{5}$ The greater is a sector's observed spatial concentration, the larger, on average, are the underlying agglomeration economies, and the lower should be the sector's locational sensitivity to tax differentials.

Empirically, there is considerable evidence to show that firm location is sensitive to differences in corporate taxes, across a range of methodological approaches. ${ }^{6}$ In the terminology of

\footnotetext{
${ }^{2}$ See Baldwin, Forslid, Martin, Ottaviano and Robert-Nicoud (2003, ch. 15, 16) for a comprehensive overview.

${ }^{3}$ Conversely, Ottaviano and van Ypersele (2005) show that in the presence of agglomeration economies, tax competition can be second-best welfare-enhancing, as it may mitigate a tendency towards excessive spatial concentration of firms.

${ }^{4}$ Due to non-monotonicity, new economic geography models also accommodate configurations where agglomeration economies in fact add to the sensitivity of firm location to tax differentials, and thus exacerbate the intensity of tax competition (Baldwin et al., 2003, Result 15.8). We focus on the configurations featuring established agglomerations, which is where these models imply qualitatively novel predictions for tax policy. Furthermore, Burbidge and Cuff (2005) and Fernandez (2005) study tax competition in models featuring increasing returns to scale that are external to firms, with firms operating under perfect competition. In these models, individual firm mobility is not constrained by agglomeration economies, and governments may compete even more vigorously to attract firms than in the standard tax competition model. Krogstrup (2008) shows that for tax competition to be intensified, external agglomeration economies must be relatively weak, in the sense that they are outweighed by dispersion forces that stabilize the overall spatial allocation of activity. Our working hypothesis is that agglomeration economies are sufficiently internalized by firms that they affect firms' locational sensitivity to tax differentials.

${ }^{5}$ More precisely, in the standard 'core-periphery' model the range of tax differentials that will not dislodge a given spatial allocation of firms is largest where agglomeration forces are strongest.

${ }^{6}$ See, e.g., Hines (1999) for a survey, and de Mooij and Ederveen (2003) for a meta-analysis.
} 
Borck and Pflüger (2006, p. 663), the 'delocation elasticity' is widely found to be negative.

Starting with Carlton (1983), numerous studies have estimated conditional logit models of firms' location choices. ${ }^{7}$ The conditional logit model has the advantage of being formally derived from a firm's stochastic profit function, but it becomes computationally demanding for estimation of models with individual data and large numbers of locational alternatives. Papke (1991) therefore suggests that location choice could also be represented by a region-level count model, such that estimation is based on maximum likelihood with an assumed Poisson distribution. ${ }^{8}$ The Poisson model is shown by Guimaraes, Figueiredo and Woodward (2003) to be formally equivalent to the conditional logit model with grouped data and group-specific fixed effects. We can therefore estimate the conditional logit model via Poisson, taking sectors as the grouping variable.

To our knowledge, only Devereux, Griffith and Simpson (2007) have previously explored the impact of agglomeration economies on the sensitivity to local fiscal incentives of firms' location choices. ${ }^{9}$ They estimate a conditional logit model of plant location in Great Britain, including an interaction term of region-level fiscal incentives with the stock of pre-existing same-sector plants in the relevant region; and they find that fiscal incentives have a greater impact on attracting plants in regions with large stocks of existing plants. As fiscal incentives in British regions are negotiated individually for each proposed new establishment, unobserved plant-level features might affect both the probability of a plant receiving a grant in a particular area and the probability of it locating in that area. Since statutory corporate taxes of Swiss regions are neither firm- nor sector-specific, our empirical setting does not present the estimation challenge affecting an analysis of the same question based on British regional grants.

Our analysis is novel in two additional ways, both motivated by a quest to tie our estimations closely to the theory. First, in our baseline specification, we focus on the interaction

\footnotetext{
${ }^{7}$ Recent applications include Guimaraes, Figueiredo and Woodward (2000), Figueiredo, Guimaraes and Woodward (2002), Crozet, Mayer and Mucchielli (2004), Head and Mayer (2004), Strauss-Kahn and Vives (2005), and Devereux, Griffith and Simpson (2007).

${ }^{8}$ Count models of firm location have subsequently been estimated by List (2001), Guimaraes, Figueiredo an Woodward (2004), and Holl (2004).

${ }^{9}$ We are aware of two other empirical studies that address the link between agglomeration and local taxation. In an analysis of the determinants of firm births in Catalonia, Solé-Ollé and Jofre-Monseny (2007) estimate the impact of local taxes with and without including controls for local agglomeration economies. They find that without controlling for agglomeration, the estimated effect of local business tax rates on firm births turns positive, which suggests that these taxes are positively correlated with local agglomeration measures. Charlot and Paty (2007) report that French municipalities with greater market potentials charge higher local business tax rates.
} 
of taxes with a sector-specific measure of agglomeration, in order to capture the essence of the new economic geography insight on tax competition. ${ }^{10}$ As long as taxes vary within the bounds beyond which they would trigger discrete ('catastrophic') relocations of mobile sectors, the theory consistently suggests that stronger sector-level agglomeration forces imply a smaller delocation elasticity. ${ }^{11}$

Second, in addition to a somewhat ad hoc 'baseline model' similar to those that have typically been estimated in this literature, we construct a 'specific model' as a representative firm's profit function that is formally derived from explicitly modeled spatial demand and supply conditions. The specific model implies that interaction terms on the tax variable are not in fact warranted, but it still allows us to compute the relative importance of taxes versus agglomeration forces in determining location choices.

\section{Models of location choice}

\subsection{A baseline model: footloose and latent startups}

At the most general level, there are two approaches to modeling the location of new firms. One approach is to consider an investor who has resolved to set up a firm somewhere among a given set of locations and then decides which location to pick. We refer to this as the 'footloose startup' model. ${ }^{12}$ The other approach is to assume that potential entrepreneurs are spatially immobile and continuously decide whether or not to set up a firm. ${ }^{13}$ We refer to this approach as the 'latent startup' model. To the empirical researcher, these two approaches are equivalent in two essential respects: the decision to set up a firm at a particular location is based in both cases on expected profits, and in both cases expected profits are best modelled

\footnotetext{
${ }^{10}$ Devereux et al. (2007), using a location-specific measure, show that it may be cheaper to attract a new plant to an existing cluster than to a peripheral location. This is an important and evidently policy-relevant result, but not what the theory necessarily predicts when the economy is in spatial equilibrium. In an interior spatial equilibrium with no relocation costs, expected profits at the locus of agglomeration (the 'central' location) and at the periphery are equalized. Whether a given change in fiscal inducements is then more effective at attracting firms to a central or to a peripheral location is indeterminate, as it depends on the functional form of the relationship between real returns and industry shares across locations. In the simulations reported by Borck and Pflüger (2006, Fig. 5), a given fiscal inducement will attract a larger number of firms if offered at the peripheral location than if offered at the central location.

${ }^{11}$ In 'core-periphery' models, which, in the absence of taxes, accommodate only perfectly agglomerated or perfectly dispersed spatial allocations of the mobile sector, marginal variations in relative tax burdens imply marginal reallocations of that sector among locations in the dispersed equilibrium but have no effect on sectoral location in the agglomerated equilibrium (see, e.g., Baldwin et al., 2003). In models that accommodate partially agglomerated configurations even in the absence of taxes, more strongly agglomerated equilibria imply lower delocation elasticities (Borck and Pflüger, 2006).

${ }^{12}$ This approach underlies the empirical literature on location choices using the conditional logit model.

${ }^{13}$ See, e.g., Becker and Henderson (2000) and Figueiredo et al. (2002).
} 
as a combination of deterministic components and a stochastic term.

We posit a general profit function for a footloose-startup decision problem, where a firm has decided to set up a new plant $f$ belonging to sector $i$ and now considers which location $j$ to choose:

$$
\pi_{f i j}=U_{i j}+\varepsilon_{f i j}=\alpha_{1} T_{j}+\alpha_{2} A_{i}+\alpha_{3} T_{j} A_{i}+\boldsymbol{\beta}^{\prime} \mathbf{x}_{i j}+\varepsilon_{f i j}
$$

$U_{i j}$ summarizes the deterministic part of the profit function that is common to firms of a particular sector and at a particular location; $T_{j}$ represents the relevant corporate tax burden at location $j ; A_{i}$ represents the strength of agglomeration economies in sector $i ; \mathbf{x}_{i j}$ is a vector of other variables that determine a firm's profits in sector $i$ at location $j$ (such as factor prices, proximity to markets, etc.); $\alpha_{1}, \alpha_{2}, \alpha_{3}$ and $\boldsymbol{\beta}$ are coefficients to be estimated; and $\varepsilon_{f i j}$ is a stochastic error term. Sectors' propensity to agglomerate, $A_{i}$, may be determined by pecuniary and/or technological spillovers, or it may be due to the spatial concentration of immobile resources that are important to sector $i$. What matters is that the locational advantages at the locus of agglomeration are at least partly internalized by firms.

Our interest is in the parameter $\alpha_{3}$ : while we expect the attractiveness of a location $j$ to fall in the level of its corporate tax burden, implying that $\alpha_{1}$ should be negative, this sensitivity should be weaker in sectors that are subject to strong agglomeration forces. A positive $\alpha_{3}$ would therefore confirm the result of the economic geography literature that agglomeration forces can offset industries' sensitivity to tax differentials.

If we treat the location decision problem as one of random profit maximization, firm $f$ will pick location $m$ if $\pi_{f i m}>\pi_{f i j} \forall j, j \neq m$. As shown by McFadden (1974), the assumption that $\varepsilon_{f i j}$ has an extreme-value type 1 distribution yields a simple expression for the probability of choosing location $m: p_{f i m}=\exp U_{f i m} *\left(\sum_{j} \exp U_{f i j}\right)^{-1}$. If we define a dummy variable $d_{f i j}$ that equals one if firm $f$ chooses location $j$ and zero otherwise, the log-likelihood of the conditional logit model becomes: $\ln L_{C L}=\sum_{f} \sum_{j} d_{f i j} \ln p_{i j}=\sum_{i} \sum_{j} n_{i j} \ln p_{i j}$, where $n_{i j}$ represents the number of firms in sector $i$ that choose location $j$.

Guimaraes et al. (2003) have shown that the same log-likelihood, up to a constant, obtains if one assumes $n_{i j}$ to be independently Poisson distributed. Thus, estimates obtained from a Poisson count regression of $n_{i j}$ on all region specific and region-sector specific regressors plus a set of sector fixed effects are equivalent to those obtained from conditional logit estimation. 
Specifically, we can rewrite the random profit model (1) equivalently as follows:

$$
E\left(n_{i j}\right)=\lambda_{i j}=\exp \left(\alpha_{1} T_{j}+\alpha_{3} T_{j} A_{i}+\boldsymbol{\beta}^{\prime} \mathbf{x}_{i j}+\gamma^{\prime} \mathbf{d}_{i}\right)
$$

where $n_{i j}$ follows a Poisson distribution and $\mathbf{d}_{i}$ is a set of sector dummies. The inclusion of sector dummies forces the control matrix $\mathbf{x}_{i j}$ to consist exclusively of variables that vary across locations. The main effect of $A_{i}, \alpha_{2}$, is absorbed into the sector fixed effects.

The latent-startup model assumes that every location hosts a certain number of immobile actual and potential new firms ('entrepreneurs') per sector. At every point in time, each potential entrepreneur computes the net present value (NPV) from becoming active and uses this to decide whether or not to start an actual firm. This yields, for every location-sector pair, a supply and demand curve for new firms in birth-NPV space. The supply curve, which rises in NPV, depends primarily on the size of a location's pool of potential entrants. The demand curve traces how the NPV per firm changes as more firms become active in the same sector and location, and its position depends on variables such as local factor costs and local product demand. Total births are then determined by the intersection of these demand and supply schedules. Becker and Henderson (2000) show that, conditional on standard regularity conditions, this model leads directly to the Poisson specification (2). By employing Poisson estimation, we can therefore accommodate both the footloose and the latent startup models - a considerable advantage given that it would be impossible based on available statistics to judge which of the two models represents a better approximation of the actual data-generating process.

\subsection{A specific model for footloose startups}

While the model of expected profits in equation (1) may be intuitive and general, it is not rooted in a formal representation of the firm's optimization problem. We now derive a profit function formally, drawing on a simple model proposed by Crozet, Mayer and Mucchielli (2004). This will lead to a particular specification of the profit function that can be viewed as an alternative to equation (1), thus offering a complementary framework for the exploration of our basic research question.

We assume identical consumer preferences across locations $j$ but allow for variations in income and price elasticities of demand across sectors $i$. A generalized Cobb-Douglas utility 
function then implies the following expression for quantity demanded $Q_{i j}$ :

$$
Q_{i j}=\frac{\phi_{i} m_{j}^{\gamma_{i}}}{p_{i j}^{\delta_{i}}},
$$

where $\phi_{i}$ is the sectoral expenditure share, $m_{j}$ is relevant income at location $j, p_{i j}$ is the price, $\gamma_{i}$ is the income elasticity, and $\delta_{i}>1$ is the price elasticity of demand.

Symmetry among firms of any sector at a particular location implies that quantity demanded, and thus equilibrium output per firm, are equalized: $q_{i j}=\frac{Q_{i j}}{N_{i j}}$, where $N_{i j}$ is the number of active firms in sector $i$ at location $j$.

Firms are assumed to be price takers in factor markets. Their unit costs are modeled as follows:

$$
c_{i j}=\left(w_{i j}\left(1+t_{j}^{w}\right)\right)^{\theta_{i}^{w}}\left(k\left(1+t_{j}^{k}\right)\right)^{\theta_{i}^{k}}\left(r_{j}\left(1+t_{j}^{r}\right)\right)^{\theta_{i}^{r}} N_{i j}^{\left(\theta^{N}+A_{i}\right)}
$$

where $w_{i j}$ is the wage rate (which may vary across locations and industries), $k$ is the capital rental price (assumed constant across locations and industries), $r_{j}$ is land rental price (which may vary across locations), $t_{j}^{w}$ is the payroll tax rate (to the extent that it is borne by employers), $t_{j}^{k}$ is the capital tax rate, $t_{j}^{r}$ is the property tax rate, $A_{i}$ again captures agglomeration economies, and the $\theta$ s are parameters. $\theta_{i}^{w}, \theta_{i}^{k}$, and $\theta_{i}^{r}$ represent input shares of labor, capital and land. The exponent on $N_{i j},\left(\theta^{N}+A_{i}\right)$, implies that firms in more agglomerated sectors will benefit more from proximity to own-sector firms than firms in less agglomerated sectors.

Profits of a representative firm can be written as $\pi_{i j}=\left(1-t_{j}^{\pi}\right)\left(p_{i j}-c_{i j}\right) q_{i j}$, where $t_{j}^{\pi}$ is the corporate income (i.e. profit) tax rate. Profit maximization with a large number of firms competing in quantities, and consideration of a multiplicative stochastic term $\nu_{f i j}$, implies the following firm-level profit function: ${ }^{14}$

$$
\begin{aligned}
\pi_{f i j}= & \left(1-t_{j}^{\pi}\right) \phi_{i} m_{j}^{\gamma_{i}}\left(\left(w_{i j}\left(1+t_{j}^{w}\right)\right)^{\theta_{i}^{w}}\right)^{1-\delta_{i}}\left(\left(k\left(1+t_{j}^{k}\right)\right)^{\theta_{i}^{k}}\right)^{1-\delta_{i}}\left(\left(r_{j}\left(1+t_{j}^{r}\right)\right)^{\theta_{i}^{r}}\right)^{1-\delta_{i}} \\
& N_{i j}^{\left(\left(\theta^{N}+A_{i}\right)\left(\delta_{i}-1\right)-2\right)} \nu_{f i j} .
\end{aligned}
$$

\footnotetext{
${ }^{14}$ See Crozet et al. (2004) for the derivation.
} 
In logs, this becomes:

$$
\begin{aligned}
\ln \left(\pi_{f i j}\right)= & \ln \left(1-t_{j}^{\pi}\right)+\ln \phi_{i}+\gamma_{i} \ln m_{j} \\
& +\left(\left(1-\delta_{i}\right) \theta_{i}^{w}\right) \ln w_{i j}+\left(\left(1-\delta_{i}\right) \theta_{i}^{w}\right) \ln \left(1+t_{j}^{w}\right) \\
& +\left(\left(1-\delta_{i}\right) \theta_{i}^{k}\right) \ln k+\left(\left(1-\delta_{i}\right) \theta_{i}^{k}\right) \ln \left(1+t_{j}^{k}\right) \\
& +\left(\left(1-\delta_{i}\right) \theta_{i}^{r}\right) \ln r_{j}+\left(\left(1-\delta_{i}\right) \theta_{i}^{r}\right) \ln \left(1+t_{j}^{r}\right) \\
& +\left(\left(\theta^{N}+A_{i}\right)\left(\delta_{i}-1\right)-2\right) \ln N_{i j} \\
& +\ln \nu_{f i j} .
\end{aligned}
$$

We can thus write the following estimable equation:

$$
\begin{aligned}
\ln \left(\pi_{f i j}\right)= & \beta_{0}+\beta_{1 i}+\beta_{2} \ln \left(1-t_{j}^{\pi}\right)+\beta_{3 i} \ln w_{i j}+\beta_{4 i} \ln r_{j}+\beta_{5 i} \ln \left(1+t_{j}^{k}\right) \\
& +\beta_{6 i} \ln \left(1+t_{j}^{w}\right)+\beta_{7 i} \ln N_{i j}+\beta_{8 i}\left(A_{i} * \ln N_{i j}\right)+\beta_{9 i} \ln m_{j}+\ln \nu_{f i j}
\end{aligned}
$$

where the $\phi_{i}$ are absorbed by sector fixed effects $\left(\beta_{1 i}\right)$, and property taxes $t_{j}^{r}$ are dropped as they do not play a role in our empirical setting. ${ }^{15}$ If we assume that $\ln \nu_{f i j}$ follows an i.i.d. extreme-value type 1 distribution, equation (5) leads to a standard conditional logit model and can be estimated, mutatis mutandis, via a Poisson count model analogous to (2). ${ }^{16}$

The principal difference between the baseline model (2) and the specific model (5) is that the latter no longer features an explicit interaction term between the corporate income tax burden and sectoral agglomeration intensity. This stems from the simple fact that a given statutory tax rate on profits reduces profits exactly proportionally irrespective of any sectoral

\footnotetext{
${ }^{15}$ The profit function (4) implies that $\beta_{2}=1$. This restriction, however, cannot be tested, because the coefficients of a multinomial choice model are identified only up to a multiplicative scale factor. Strictly, (4) also implies that $\beta_{3 i}=\beta_{6 i}$, i.e. that the effect of a percentage change in wages is equivalent to that of a percentage change in the tax on wages. We shall not impose this restriction, because (a) we observe taxes on personal income (whose incidence on firms' wage bills we cannot measure) and (b) our data for wages and for personal income taxes are at different spatial scales. Moreover, for expositional simplicity we shall report results with $\beta_{5 i}, \beta_{6 i}, \beta_{7 i}$, and $\beta_{8 i}$ each constrained to be equal across sectors, i.e. we assume the effects of taxes on factor inputs and the main effect of $N_{i j}$ (which we shall represent by the empirical variable sector proximity) to be the same across sectors. To the extent that they are possible, estimations with sector-level effects of these variables yield qualitatively equivalent results to those reported below. Given the very limited time variation in our data, separate identification of $\beta_{7 i}$, and $\beta_{8 i}$ is not feasible.

${ }^{16}$ Silva and Tenreyro (2006) show that the Poisson estimator is particularly well suited to log-linear regression specifications that are derived from multiplicative models with potentially heteroskedastic error terms.
} 
or locational specificities. Hence, we shall compute an indirect "tax-versus-agglomeration effect" for the specific model, based on the magnitude of the estimated tax sensitivity parameter $\beta_{2}$ relative to the magnitude of the estimated agglomeration sensitivity parameters $\beta_{7}$ and $\beta_{8}$.

\subsection{Estimation issues}

\subsubsection{Scaling}

In estimating our models (2) and (5), we need to take account of the fact that real-world locations come in different geographic sizes, giving them different probabilities of attracting or generating a certain number of new firms even once their purely economic characteristics are accounted for. Failure to control for size differences could thus lead to omitted-variable bias.

We can think of our locations $j$ as consisting of $L_{j}$ equally sized 'lots' $\ell \in \mathcal{L}_{j}$. Characteristics of individual lots are only observed (or are only relevant) at the level of locations.

Assume a conditional logit model at the level of lots. The profit function for firm $f$ associated with lot $\ell$ in location $j$ (suppressing industry-level notation) is given by $\pi_{f \ell}=$ $U_{f j}+\varepsilon_{f \ell}$, where $\varepsilon_{f \ell}$ is independent across $f$ and $\ell$ and follows an extreme-value type 1 distribution. Note that the deterministic part $U_{f j}$ is equal across lots within location $j$. Then the probability that firm $f$ chooses a lot in location $m$ is given by

$$
p_{f m}=\sum_{\ell \in \mathcal{L}_{m}} p_{\ell}=\sum_{\ell \in \mathcal{L}_{m}} \frac{\exp U_{f m}}{\sum_{\ell} \exp U_{f j}}=\frac{L_{m} \exp U_{f m}}{\sum_{j} L_{j} \exp U_{f j}}=\frac{\exp \left(U_{f \ell_{m}}+\ln L_{m}\right)}{\sum_{j} \exp \left(U_{f j}+\ln L_{j}\right)} .
$$

This is equivalent to a conditional logit model at the level of locations with profit function $\pi_{f j}=U_{f j}+\ln L_{j}+\varepsilon_{f j}$, where $\varepsilon_{f j}$ is independent across $f$ and $j$ and follows an extreme-value type 1 distribution. The number of lots $L_{j}$ in location $j$ can be computed as economically usable land area $S_{j}$ divided by lot area $\bar{s}$. The profit function at the level of locations then becomes

$$
\pi_{f j}=\tilde{U}_{f j}+\ln S_{j}+\varepsilon_{f j}
$$

where the constant lot size only affects the intercept of the deterministic part $\tilde{U}_{f j}=$ $U_{f j}-\ln \bar{s}$ 
We therefore include usable land area as a control variable in all our estimated regressions. Taken literally, expression (6) suggests that the coefficient on log area should be equal to one. We shall test the robustness of our results to the formal imposition of this restriction in the specific model.

\subsubsection{Unobserved location-specific effects}

In the context of location choice modelling, Poisson estimation allows the researcher to adhere rigorously to the random profit-function model. It does not, however, relax the 'independence of irrelevant alternatives' (IIA) assumption, which arguably represents the major drawback of the conditional logit approach. IIA implies that stochastic terms are independent across locations. This assumption is violated if there are relevant location-specific characteristics that are spatially correlated but unobserved by the econometrician. A useful palliative is to include location-specific fixed effects, controlling for all unobserved location-specific characteristics (Guimaraes et al., 2004). Our baseline model (2) thus becomes:

$$
E\left(n_{i j}\right)=\lambda_{i j}=\exp \left(\alpha_{3} T_{j} A_{i}+\boldsymbol{\beta}^{\prime} \mathbf{x}_{i j}+\gamma^{\prime} \mathbf{d}_{i}+\boldsymbol{\delta}^{\prime} \mathbf{d}_{j}\right)
$$

where $\mathbf{d}_{j}$ is a set of location dummies. This approach no longer allows identification of coefficients on purely location-specific characteristics such as $T_{j}$. Since we are interested in this effect as well as in coefficients on certain other certain purely location-specific variables, we estimate our models both with and without location-specific fixed effects, taking the former as robustness tests for the latter.

\subsubsection{Overdispersion and excess zeroes}

The estimable Poisson model is formally derived from the underlying profit functions. This establishes a direct link between theory and empirics. The Poisson model implies that the expected count, $\lambda_{i j}$, is equal to the variance of $n_{i j}$. This is typically a strong assumption in empirical applications, as the variance often exceeds the expected count (overdispersion), and as economic data often feature a larger number of zero observations than that implied by the Poisson distribution. ${ }^{17}$ We address these issues in two ways. For the standard fixed-

\footnotetext{
${ }^{17}$ In our data, the share of zero observations ranges from 73.3 percent at the two-digit level of sectoral aggregation to 89.7 percent at the four-digit level.
} 
effects panel Poisson estimates we additionally report robust standard errors, and we estimate zero-inflated panel Poisson. ${ }^{18}$

\section{The empirical setting}

\subsection{Local taxation in Switzerland}

We base our estimations on data for Switzerland. For a number of reasons, the Swiss fiscal system provides an ideal laboratory in which to examine our research question.

Swiss sub-federal jurisdictions enjoy almost complete autonomy in the determination of their tax rates, and, as a consequence, we observe large variations in tax burdens even within the small area covered by Switzerland. ${ }^{19}$ The Swiss federation consists of three government layers (federal, cantonal and municipal), with each jurisdictional level collecting a roughly similar share of total tax revenue.

In the Swiss fiscal system, corporate taxation is mainly the remit of sub-federal jurisdictions. Cantons and municipalities collect around 65 percent of the total tax income raised on corporate income and capital, the remaining 35 being raised by the federal government. Hence, differences in corporate taxes across cantons and municipalities matter, and they are large. Figure 1 illustrates this point for consolidated cantonal-plus-municipal corporate income taxes on profits of a representative firm with a 2 percent return on capital: the highest tax rate, at 14.1 percent, is almost seven times higher than the lowest rate, at 2.1 percent.

Another advantage of the Swiss system is that corporate taxation is based on legally binding statutory rates that depend solely on firms' profitability and capital base. Statutory rates apply identically across sectors and firms. Differences in tax burdens across municipalities and cantons can therefore be considered as exogenously given from the point of view of individual firms. Since identical tax treatment applies across sectors, and our data allow for analysis at the level of narrow sectors, we can also abstract from the possibility that the intensity of spatial concentration in certain sectors could be influenced by the level and spatial distribution

\footnotetext{
${ }^{18}$ See Winkelmann (2000) on these approaches to estimation and inference with panel count data, and List (2001) for an application of the zero-inflated Poisson estimator to models of location choice. Since the ZIP estimator breaks the formal link between the theoretical profit function and the empirical model, we consider it as a sensitivity check on the Poisson regressions. On robust standard errors in panel Poisson models, see Wooldridge (1999)

${ }^{19}$ Switzerland has an area of 41,285 square kilometres and a population of 7.5 million. It therefore covers about twice the area, and hosts roughly the same population, as the US state of Massachusetts.
} 
of corporate tax burdens. ${ }^{20}$

\subsection{Data sources}

We draw on data from three main sources.

First, the Swiss Federal Statistical Office has collected information on every newly created firm annually since $1999 .{ }^{21}$ The main use of this data set is as the source of new firm counts per municipality and economic sector $\left(n_{i j}\right)$, our dependent variable. We use data for the years 1999-2002. This database offers information on the municipality in which the new firm is located and on the firm's main sector of activity in terms of the two-, three- and fourdigit sectors of the European NACE classification system. ${ }^{22}$ The data set records as new firms all market-oriented business entities that have been founded in the year concerned and are operating for at least 20 hours per week. New entities created by mergers, takeovers or breakups are not counted. A foreign firm's first Swiss branch, however, counts as a new firm. Observed firm start-ups undoubtedly represent a mixture of births through resident entrepreneurs best modelled by the latent-startup approach and of births by non-resident (Swiss or foreign) investors best modelled by the footloose-startup approach.

Our second source of data is the multiannual census of all firms located in Switzerland, also carried out by the Federal Statistical Office. We use data for the surveys of 1998 and 2001, containing information on location, sector of activity and employment, to construct our agglomeration variables.

Finally, we have assembled a municipality-level dataset on local taxes and other control variables from a variety of sources. ${ }^{23}$ We use these data for our measures of corporate and income tax burdens, factor prices, public expenditure, and proximity to markets. The data were collected for 1998 and 2001, covering the 213 largest municipalities. The mean population of our sample municipalities is 17,367 , for a mean total area of 20.2 square kilometers. ${ }^{24}$

\footnotetext{
${ }^{20}$ For models of endogenous agglomeration, driven in part by taxation patterns, see e.g. Ottaviano and van Ypersele (2005), and Haufler and Wooton (2007).

${ }^{21}$ The statistical office's title for this project is "Unternehmensdemografie" (UDEMO).

${ }^{22}$ We retain only sectors that pertain to the private sector. Furthermore, sectors for which no firm births are observed in either year are dropped from the dataset. This leaves us with 41 sectors at the two-digit level, 133 sectors at the three-digit level, and 242 sectors at the four-digit level.

${ }^{23}$ For a detailed description of the data on municipal taxes and other municipal attributes, see Brülhart and Jametti (2006).

${ }^{24}$ Due to the small size of our sample jurisdictions, we feel confident in abstracting from within-juristictional heterogeneity. Duranton, Gobillon and Overman (2007) provide a careful treatment of this issue based on data for English Local Authorities (which, on average, cover areas that are 18 times larger than our Swiss sample municipalities).
} 


\subsection{Variables used}

\subsubsection{Dependent variable}

We run all of our regressions for two waves of firm creations, which we pool while allowing for separate intercepts. Counts of new firms set up over the period 1999-2000 are assigned to control variables for 1998, and counts of new firms set up over the period 2001-2002 are assigned to control variables for 2001. The average number of new firms $\left(n_{i j}\right)$ at the threedigit level is 0.486 and 0.440 in our two sample periods respectively. By multiplying these averages with the number of sector-municipality observations in each sample period, we find nationwide totals of 13,768 new firms in 1999-2000 and 12,465 new firms in 2001-2002.

\subsubsection{Explanatory variables: baseline model}

Our main explanatory variables in the baseline model $(2)$ are local corporate taxes $\left(T_{j}\right)$, sectoral agglomeration economies $\left(A_{i}\right)$ and, most importantly, the interaction of those two effects. We represent local corporate taxes via a tax index, a revenue-weighted average of consolidated municipal and cantonal profit and capital taxes. The index is calculated separately for 1998 and for 2001. Corporate income tax schedules are progressive in most municipalities. Hence, we collected statutory corporate income tax rates for three representative levels of profitability (2, 9 and 32 percent, based on observed distributions of profitability levels in Swiss firm-level statistics), and took the mean of these three rates as an index for the corporate income tax. As capital taxes are generally proportional, we collected statutory capital tax rates for a firm with the median capital base. To compute the tax index, we normalized the profit-tax index and the capital tax rates by subtracting the mean and dividing by the standard deviation for each of the two sample years, and we weighted them by the respective importance in terms of tax revenue. Hence, the tax index has mean zero by construction. ${ }^{25}$

Agglomeration economies are not directly observable. In steady state, however, sectors subject to strong agglomeration economies will be more spatially concentrated than sectors subject to weak agglomeration economies (or to net dispersion economies). Hence, we compute spatial concentration indices using the definition proposed by Ellison and Glaeser (1997), which controls for differences in firm numbers across sectors in quantifying the extent of

\footnotetext{
${ }^{25}$ Table 1 provides summary statistics, and Figure 2 illustrates the distribution of tax indices across cantons. None of our results hinges on the construction of this variable. Results for our baseline model using statutory tax rates instead of the tax index can be provided on request.
} 
geographic clustering. We refer to this variable as the $E G$ index. We cannot estimate the main effect of the EG index, due to the inclusion of sector-specific fixed effects. Our coefficient of interest in the baseline model (2), however, is $\alpha_{3}$, the effect of the interaction between the tax index and the EG index. We compute this interaction by multiplying the two indices after mean-differencing the EG index (the tax index has mean zero by construction). Thereby, the interaction term has a mean of zero, which allows us to interpret the estimated coefficient on the tax index as the effect of taxes for a sector with average spatial concentration.

A number of control variables are included $\left(\mathbf{x}_{i j}\right)$. In order to allow for cost factors affecting firm profits, we control for the prices of labour and of real estate. ${ }^{26}$ Wage reports average monthly wages per sector and region, while property price stands for the average selling price of a representative family home. ${ }^{27}$ In the baseline model, we interact both these price variables with the $E G$ index, as we may expect equivalent effects of agglomeration economies for the importance of factor prices to those we hypothesize for local tax rates: the stronger are sectorspecific agglomeration economies, the less sensitive firms' location decisions should be, other things equal, to differentials in factor prices across municipalities.

As income taxes may affect firms' location choices in addition to corporate taxes, we also include the variable income tax, which represents the canton-averaged statutory cantonalplus-municipal income tax rate for a median-income representative household. We choose this measure, which is invariant across municipalities within each canton, because distances within cantons are sufficiently small to allow easy commuting among municipalities. Hence, income taxes in the particular municipalities where firms are located would not be the relevant measure. ${ }^{28}$ Similarly, we control for public expenditure, computed as canton-averaged municipal-plus-cantonal expenditures on what might be considered the main spending items from the viewpoint of private-sector firms: education, public safety and transport. Again, selecting only municipality-specific expenditure would not represent the relevant variable, as

\footnotetext{
${ }^{26}$ We assume that the price of capital is equalized across Swiss municipalities.

${ }^{27}$ Wage is available from the Swiss national statistical office for the year 2000, at a level of sectoral aggregation corresponding roughly to one-digit NACE, and at the level of regions comprising several cantons ("Grossregionen"). It is thus assumed that relative wages are constant over our sample period, among subsectors and within regions. Property price is available from the consultancy firm Wüest \& Partner for the year 2002. It is assumed that relative property prices did not vary significantly over our sample period. Since commercial property prices are not collected at a sufficient level of detail for our purpose, we employ prices of private property as the best approximation.

${ }^{28}$ We have also performed our estimations by replacing the canton-averaged tax rate on a median-income household by (i) the municipal median-income tax rate, (ii) the canton-mean maximum (i.e. high-income) tax rate, and (iii) inversely distance weighted averages of municipal tax rates. All our qualitative results are unaffected by variations in the definition of income tax.
} 
Swiss municipalities are sufficiently small to commute to from outside. ${ }^{29}$

Proximity to same-sector firms is the key cost factor stressed in the recent economic geography literature - either as a source of technological spillovers, specialized production factors and intermediate inputs, or as factor affecting the intensity of local competition. We therefore control for sector proximity, by computing separately for each municipality and for 1998 and 2001 the inversely distance weighted number of existing firms in the relevant sector across all Swiss municipalities. The main demand-side control variable is market potential, which, for each municipality, is defined in the conventional way as the inversely distance weighted average income across all Swiss municipalities. ${ }^{30}$ As a simple complementary measure, we also include distance to highway, the road distance to the nearest access point to the highway network. This variable, unlike sector proximity and market potential, has the advantage of measuring accessibility without implying that the relevant economic space ends at the national border. Summary statistics on these variables are provided in Table 1. We furthermore include a dummy variable for assisted municipalities, which are defined as lying within a region identified by federal law as eligible for temporary tax exemptions for newly created firms. ${ }^{31}$ Finally, we control for area, for consistent estimation given unequally sized locations (see Section 3.3.1). In defining this variable, we consider only built-up and constructible surfaces.

\subsubsection{Explanatory variables: specific model}

Estimation of our specific model (5) requires a subset of the variables used in the baseline model, measured in logs. An important difference is that we need to identify the relevant tax rates. We have therefore collected statutory tax rates on representative tax payers for taxes on corporate income $\left(t_{j}^{\pi}\right)$, capital $\left(t_{j}^{k}\right)$ and personal income $\left(t_{j}^{w}\right) .{ }^{32}$ Since these statutory

\footnotetext{
${ }^{29}$ Using a broader measure of public expenditure does not affect any of our qualitative results but leads to somewhat weaker effects of the expenditure variable.

${ }^{30}$ In the construction of these two variables, we weight by the square of euclidian distance between the geographic centers of municipalities. Square weights appear more appropriate than linear weights, considering the existing evidence on spatial decay functions based on intra-national commuting patterns (e.g. Harsmann and Quigley, 1998). Municipal incomes are estimates reported by the Swiss federal statistical office for 1992, the latest available year.

${ }^{31}$ According to Swiss law, some (mainly industrial) firms can be offered tax rebates for a maximum of ten years after setting up an operation. No data are made available for cantonal and municipal exemptions granted, but it is probable that they are correlated with the eligibility for tax holidays at the federal level. Furthermore, rules governing such practices are co-ordinated across cantons, such that they are unlikely to add significantly to differences in fiscal burdens across jurisdictions.

${ }^{32}$ Based on fiscal statistics for Switzerland, we define representative profitability as 9 percent of own capital, we take a representative capital stock as 176,000 and 181,000 Swiss francs respectively in 1998 and 2001, and we consider canton-averaged income tax rates on a household with two children and a taxable annual income of 73,000 and 75,000 Swiss francs respectively in 1998 and 2001. One Swiss franc traded for 0.63 US dollars
} 
tax rates may be sensitive to our definition of representative tax payers, we also estimate the specific model using the tax index described above instead of the statutory rates.

\section{Results}

\subsection{Some Preliminary Illustrations}

Before reporting econometric estimates, we provide some illustrative examples of our central result. Figures 3,5 and 7 show maps of the geographic distribution of establishments in three sectors: software development and consulting (NACE 722), production of clothing (NACE 182), and brokerage and wealth management (NACE 671). These sectors are shown in increasing order of their measured geographic concentration, the first two sectors having below-average $E G$ indices, and the third sector displaying an $E G$ index above the overall average of 0.013. The corresponding Figures 4, 6 and 8 plot counts of new firms, scaled by area, in 1999-2000 over the 1998 tax index of all municipalities that have witnessed firm births over the relevant period. We observe that the relationship between taxes and firm births becomes gradually less negative as we move down the list of sectors. While the relationship between taxes and firm births is negative and statistically significant at the 1 percent level for software development and consulting, this relationship turns positive, although not statistically significant, for brokerage and wealth management. These examples illustrate our main point: the more spatially concentrated a sector, the less firm births in that sector are deterred by high local corporate taxes (or attracted by low taxes).

\subsection{Baseline Model}

\subsubsection{Parameter estimates with sector fixed effects}

We begin by estimating our baseline model including fixed effects for sectors but not for municipalities, which allows us to identify coefficients on municipality-specific variables. The first panel of Table 2 reports estimates of specification (2) separately for the three levels of sectoral aggregation distinguished in our data. To jump straight to the main result, focusing on the 3-digit and 4-digit regression runs: while, as expected, the coefficient on the tax index is statistically significantly negative, the interaction term with the $E G$ index is statis-

on average over our sample period. 
tically significantly positive. These estimations therefore confirm the hypothesis we seek to test: location choices of firms in more spatially concentrated sectors are less sensitive to tax differentials.

The estimated coefficients on the included control variables largely conform with expectations. We find consistently negative coefficients on wage and distance to highway, and positive coefficients on public expenditure, area, sector proximity and market potential. ${ }^{33}$ Interactions of wage and property price with the EG index, reflecting the prediction that firms' sensitivity to factor prices other than taxes is also lessened as they experience stronger co-location economies, return positive estimated coefficients, in line with expectations.

The only unexpected result is that property price appears to affect the rate of firm creation positively. The most plausible explanation for this result is that property price correlates with unobserved location-specific features that are attractive to new firms but not fully capitalized in property prices. We therefore interpret this result as suggesting omitted variables at the municipality level, which supports our use of alternative estimation strategies that involve the inclusion of municipality-level fixed effects.

As a complement to the Poisson estimates we report results of specification (2) based on a zero-inflated Poisson model in the second panel of Table 2. The results are not substantially affected by this change of estimator. Our main coefficients of interest, on the tax index and on the interaction of the tax index with the $E G$ index, have similar magnitudes across the two sets of results, and the signs are identical throughout.

\subsubsection{Parameter estimates with sector and location fixed effects}

Table 3 presents estimation results for specification (7) of the baseline model, which includes municipality fixed effects in addition to the sector fixed effects. The inclusion of municipalityspecific effects implies that we can no longer identify the coefficients on variables that do not vary across sectors (tax index, property price, income tax, public expenditure, area, market potential, distance to highway). Any bias due to unobserved but relevant time and sector

\footnotetext{
${ }^{33}$ We have also experimented with variables capturing municipality-level human capital (measured by average educational attainment). Educational attainment turns out to be strongly collinear with market potential, and inclusion of human-capital variables can yield negative estimated coefficients on market potential. This is consistent with models in which centrality (generally implying location in an urban area) is attractive mainly because of the access it offers to a skilled workforce and in spite of local congestion diseconomies (see, e.g., Combes, Duranton and Gobillon, 2008). None of the remaining coefficients are significantly affected when human capital is included. Results can be provided on request.
} 
invariant locational features, however, can now be avoided..$^{34}$

Our main interest concerns the interaction of the tax index with the EG index. The estimated coefficients are somewhat smaller in magnitude, but they are again consistently positive; and, based on the robust variance estimators, statistical significance is found in two out of the three regression runs. Our key result is thus confirmed: the more agglomerated a sector, the less its firms react to tax differentials in choosing locations.

In line with expectations, significantly positive effects are also found on the interaction of property price with the EG index, and on sector proximity. Neither the main effect of wage nor its interaction with the EG index, however, is statistically significant. This is not very surprising, as we observe wages only at the level of large regions and not of individual municipalities.

\subsubsection{Importance of agglomeration on firms' sensitivity to tax differentials}

The coefficients reported in the first panel of Table 2 reveal that for a firm in a sector with an EG index of zero, corporate taxes exert a statistically significantly negative impact on location choice. We can quantify this effect by computing the relative change in new firm counts of a one-standard-deviation change in the tax index (see e.g. Winkelmann, 2000):

$$
\frac{E\left(n_{i j} \mid T_{j}+1 * \operatorname{std}\left(T_{j}\right)\right)-E\left(n_{i j} \mid T_{j}\right)}{E\left(n_{i j} \mid T_{j}\right)}=\exp \left(\left(\widehat{\alpha}_{2}+\widehat{\alpha}_{3} A_{i}\right) * \operatorname{std}\left(T_{j}\right)\right)-1 .
$$

The estimated parameters at the three-digit level, for example, imply that an increase in a municipality's tax index by one sample standard deviation (of 0.64) decreases the count of firms in a sector with average agglomeration intensity ( $E G$ index of 0.013 ) setting up in that municipality by 3.8 percent.

For a weakly agglomerated sector, at the twentieth percentile of the sample distribution of the $E G$ index, the tax deterrent effect is considerably stronger, at -6.7 percent. Conversely, at the eightieth percentile of the distribution of the $E G$ index, the impact of a one-standarddeviation increase in the tax index on the count of new firms shrinks to -3.3 percent. Hence, location choices of firms in sectors with an agglomeration intensity at the twentieth percentile of the sample distribution are twice as responsive to a given change in municipal corporate tax burdens as firms in sectors with an agglomeration intensity at the eightieth percentile

\footnotetext{
${ }^{34}$ One such feature might be the bureaucratic costs of registering a new firm.
} 
of the sample distribution. To give two examples, firms in the software sector (NACE 722), whose $E G$ index corresponds to the twentieth percentile, are predicted to be twice as sensitive to corporate tax differentials as firms in the specialized machinery sector (NACE 295), whose $E G$ index corresponds to the eightieth percentile. Our results therefore imply differences in locational sensitivities that are quantitatively important. ${ }^{35}$

\subsection{Specific model}

\subsubsection{Parameter estimates}

The first panel of Table 4 reports our estimates of the specific model (5), with all coefficients constrained to be equal across sectors (allowing us to report them in the table). Again, we find that high corporate taxes deter firm births, with an effect of the corporate income tax rate that is statistically significantly negative across the three regression runs. Note that the positive coefficient estimated on $\ln \left(1-t_{j}^{\pi}\right)$ implies that the effect of the tax rate is negative.

The effects of income tax and capital tax are also estimated to be negative. The effect of capital taxes appears considerably weaker than that of corporate and personal income taxes. This can probably be explained by the fact that capital taxes play a relatively minor role in the Swiss fiscal system, accounting for a mere three percent of consolidated tax revenues at the sub-federal level (whereas corporate income taxes represent some twelve percent and personal income taxes about two thirds of total sub-federal revenues).

Conversely, agglomeration effects, measured here as the coefficient on the interaction between sector proximity and the EG index, are positive and statistically significant (although with robust standard errors statistical significance is found only at the three-digit level of sectoral aggregation). The remaining controls perform in line with expectations: a large area, high sector proximity and high market potential raise the number of new firms, while a high average wage appears to be detrimental. The estimated coefficients on property price are not statistically significant, which is again suggestive of a dual role played by this variable, both as a factor price (which deters firm births) and as a positive but imperfect correlate of unmeasured locational attractions (which promote firm births), thus supporting inclusion of

\footnotetext{
${ }^{35}$ At the ninetieth percentile of the distribution of the $E G$ index, the implied effect of corporate taxes is still negative. It is only when we move to the 95 th percentile, i.e. for firms in a very strongly agglomerated sector, that the estimates imply a positive relation between the tax index and new firm counts (of 7.4 percent). Our results therefore suggest, in accordance with expectations, that high corporate taxes are a deterrent to firm location in well over 90 percent of sectors.
} 
municipality fixed effects to test the sensitivity of our parameters of main interest.

We then carry out a number of robustness tests on the regressions reported in the first panel of Table 4.

In the second panel of Table 4, we show results for the same specification but estimated via zero-inflated Poisson. The estimated coefficients are stable, and the precision of the estimates is increased. In particular, we now find that the interaction between sector proximity and the $E G$ index is statistically significant at all levels of sectoral aggregation also when based on robust standard errors. Overall, therefore, even the constrained version of our specific model (in the sense that estimated coefficients are forced to be equal across sectors) performs well.

The first panel of Table 5 reports estimates of a specification that allows for sector-specific coefficients on wage, property price and market potential and thereby gets closer to expression (5). ${ }^{36}$ Once more, our main results stand: high corporate and personal income taxes depress firm births, whereas firms in highly agglomerated sectors, measured by the $E G$ index, choose locations with high sector proximity. Our qualitative results also hold once we force the coefficients on area to unity, as suggested by the empirical model in Section 3.3.1. These estimates are reported in the second panel of Table $5 .^{37}$

As another robustness test, we again introduce municipality fixed effects. This no longer allows us to identify the effect of the tax variables, but it serves as a check on the interaction between sector proximity and the EG index in a specification that controls for all potential municipality-level determinants of firm births. Table 6 displays the results. We once more find positive estimates on the interaction of interest, with robust statistical significance, however, found only at the three-digit level of sectoral aggregation.

Finally, we replace our statutory corporate tax variables with the tax index for corporate income and capital taxes as used in the baseline model. To use the tax index, while loosening the link to the specific model, has the advantage of capturing the full tax schedules better than statutory taxes for particular types of firms and households. These results are reported in Table 7 (which apart from the modified tax variables corresponds to the specification reported on in Table 4). We find statistically significant deterrent effects of corporate and

\footnotetext{
${ }^{36}$ We report results for interactions of these three variables with dummies for one-digit sectors. Due to space constraints, we report test statistics for the joint significance of each set of coefficients rather than listing all the individual estimates. Interactions with dummies for more disaggregated sectors do not substantially alter our results. We have also found our findings to be robust to sector-by-sector estimation of the tax variables.

${ }^{37}$ We furthermore find the results not to be substantively affected if instead of Poisson we employ the zeroinflated Poisson estimator for these regression runs.
} 
personal income taxes across the board. All remaining coefficients, including those on the agglomeration variables, are very similar to those obtained in the estimations based on the tax index (Table 4). We therefore conclude that our results are not driven by any particular - and inevitably somewhat arbitrary - empirical representation of the relevant corporate and personal tax burdens.

\subsubsection{Tax-versus-agglomeration effect}

Our specific model implies that the elasticity of profits, and thus of new firm counts, with respect to corporate income taxes is constant. Hence, unlike our baseline specification (1), the specific model (5) does not feature an explicit interaction between taxes and agglomeration forces. However, the agglomeration force, i.e. the effect on profits of a large $N_{i j}$, will be sector specific. According to equation (5), the total agglomeration effect on profits is $\frac{\partial \ln \pi_{i}}{\partial \ln N_{i}}=$ $\beta_{7}+\beta_{8} A_{i}$, which varies across sectors via the different agglomeration intensities $A_{i} \cdot{ }^{38}$ Having estimated the parameters of equation (5), we will thus be able to compute how the sensitivity of profits with respect to the local corporate tax index $\left(\beta_{2}\right)$ varies relative to the elasticity of profit with respect to the number of proximate own-sector firms:

$$
\text { Tax-Versus-Agglomeration Effect }=\frac{\widehat{\beta}_{2}}{\widehat{\beta}_{7}+\widehat{\beta}_{8} A_{i}},
$$

where circumflexes denote estimated values.

An illustration of this effect, based on the three-digit unconstrained Poisson results of Table 5, is provided in Figure 9. Confidence intervals are computed using the delta method, based alternatively on unadjusted and on robust Poisson standard errors. The illustration shows that the relative importance of tax differentials is some 2.5 times stronger for the least agglomerated sectors than for the most agglomerated sectors. ${ }^{39}$ We again find, therefore, that the intensity of agglomeration affects the relative importance of tax differentials in determining firms' location choices to a quantitatively significant extent.

\footnotetext{
${ }^{38}$ Recall that we constrain $\beta_{7 i}$, and $\beta_{8 i}$ in (5) to be equal across sectors, as our data would not allow us to identify them separately at the sector level.

${ }^{39}$ The $E G$ index in our sample ranges from -0.050 to 0.279 (see Table 1).
} 


\section{Conclusions}

Drawing on a firm-level dataset for Switzerland and employing fixed-effects count-data estimation techniques, we find that firm births on average react negatively to corporate tax burdens, but that the deterrent effect of taxes is significantly weaker in sectors that are more spatially concentrated. This finding supports the validity of recent theoretical results suggesting that agglomeration economies can reduce the importance of tax differentials for firms' location choices and thereby lessen the intensity of corporate tax competition even if technological and administrative barriers to capital mobility are low.

In a sense, this research constitutes but the first step in a full evaluation of the prediction that agglomeration forces mitigate 'race-to-the-bottom' tax competition. Although tax competition is often at its fiercest when targeted at new firms, it could be useful to explore how tax differentials affect not just births but the entire life cycle of firms, including expansions, contractions and deaths. In future work it will furthermore be interesting to study whether policy makers recognize the differential impact of fiscal inducements across sectors and effectively tax agglomeration rents, and whether this effect is strong enough to have a noticeable impact on the evolution of statutory corporate tax burdens.

\section{References}

[1] Andersson, Fredrik and Rikard Forslid (2003) Tax Competition and Economic Geography. Journal of Public Economic Theory, 5(2): 279-303.

[2] Baldwin, Richard E. and Paul Krugman (2004) Agglomeration, Integration and Tax Harmonisation. European Economic Review, 48(1): 1-23.

[3] Baldwin, Richard E.; Rikard Forslid; Philippe Martin; Gianmarco I.P. Ottaviano and Frédéric Robert-Nicoud (2003) Economic Geography and Public Policy. Princeton University Press.

[4] Becker, Randy and Vernon Henderson (2000) Effects of Air Quality Regulations on Polluting Industries. Journal of Political Economy, 108(2): 379-421.

[5] Borck, Rainald and Michael Pflüger (2006) Agglomeration and Tax Competition, European Economic Review, 50(3): 647-668.

[6] Brülhart, Marius and Mario Jametti (2006) Vertical Versus Horizontal Tax Externalities: An Empirical Test. Journal of Public Economics, 90(10): 2027-2062.

[7] Burbidge, John and Katherine Cuff (2005) Capital Tax Competition and Returns to Scale. Regional Science and Urban Economics, 35: 353-373.

[8] Carlton, Dennis W. (1983) The Location and Employment Choices of New Firms: An Econometric Model with Discrete and Continuous Endogenous Variables. Review of Economics and Statistics, 65: 440-449. 
[9] Charlot, Sylvie and Sonia Paty (2007) Market Access Effect and Local Tax Setting: Evidence from French Panel Data. Journal of Economic Geography, 7(3): 247-263.

[10] Combes, Pierre-Philippe; Gilles Duranton and Laurent Gobillon (2008) Spatial Wage Disparities: Sorting Matters! Journal of Urban Economics, forthcoming.

[11] Crozet, Matthieu; Thierry Mayer and Jean-Louis Mucchielli (2004) How Do Firms Agglomerate? A Study of FDI in France. Regional Science and Urban Economics, 34(1): $27-54$.

[12] De Mooij, Ruud A. and Sjef Ederveen (2003) Taxation and Foreign Direct Investment: A Synthesis of Empirical Research. International Tax and Public Finance, 10(6): 673-693.

[13] Devereux, Michael P.; Rachel Griffith and Helen Simpson (2007) Firm Location Decisions, Regional Grants and Agglomeration Externalities. Journal of Public Economics, 91(3-4): 413-435.

[14] Duranton, Gilles; Laurent Gobillon and Henry G. Overman (2007) Assessing the Effects of Local Taxation Using Microgeographic Data. Mimeo. University of Toronto, Institut National d'Etudes Démographiques, and London School of Economics.

[15] Ellison, Glenn and Edward L. Glaeser (1997) Geographic Concentration in U.S. Manufacturing Industries: A Dartboard Approach. Journal of Political Economy, 105(5): 889-927.

[16] Feld, Lars P. and Gebhard Kirchgässner (2003) The Impact of Corporate and Personal Income Taxes on the Location of Firms and on Employment: Some Panel Evidence for the Swiss Cantons. Journal of Public Economics, 87(1): 129-155.

[17] Fernandez, Gonzalo E. (2005) A Note on Tax Competition in the Presence of Agglomeration Economies. Regional Science and Urban Economics, 35(6): 837-847.

[18] Figueiredo, Octávio; Paulo Guimaraes and Douglas Woodward (2002) Home-Field Advantage: Location Decisions of Portuguese Entrepreneurs. Journal of Urban Economics, 52(2): 341-361.

[19] Guimaraes, Paulo; Octávio Figueiredo and Douglas Woodward (2000) Agglomeration and the Location of Foreign Direct Investment in Portugal. Journal of Urban Economics, 47(1): 115-135.

[20] Guimaraes, Paulo; Octávio Figueiredo and Douglas Woodward (2003) A Tractable Approach to the Firm Location Decision Problem. Review of Economics and Statistics, 85(1): 201-204.

[21] Guimaraes, Paulo; Octávio Figueiredo and Douglas Woodward (2004) Industrial Location Modelling: Extending the Random Utility Framework. Journal of Regional Science, 44(1): 1-20.

[22] Harsmann, Björn and John M. Quigley (1998) Education, Job Requirements, and Commuting: An Analysis of Network Flows. In M.J. Beckerman et al. (eds.), Knowledge and Networks in a Dynamic Economy, Springer.

[23] Haufler, Andreas and Ian Wooton (2007) Competition for Firms in an Oligopolistic Industry: Do Firms or Countries Have to Pay? CESIfo Working Paper \#1976.

[24] Head, Keith and Thierry Mayer (2004) Market Potential and the Location of Japanese Investment in the European Union. Review of Economics and Statistics, 86(2): 959-972.

[25] Hines, James R. (1999) Lessons from Behavioral Responses to International Taxation. National Tax Journal, 53(2): 305-322.

[26] Holl, Adelheid (2004) Manufacturing Location and Impacts of Road Transport Infrastructure: Empirical Evidence from Spain. Regional Science and Urban Economics, 34(3): 341-363. 
[27] Kind, Hans J.; Karen H. Midelfart Knarvik and Guttorm Schjelderup (2000) Competing for Capital in a 'Lumpy' World. Journal of Public Economics, 78(3): 253-274.

[28] Krogstrup, Signe (2008) Standard Tax Competition and Increasing Returns. Journal of Public Economic Theory, forthcoming.

[29] List, John A. (2001) US County-Level Determinants of Inbound FDI: Evidence from a Two-Step Modified Count Data Model. International Journal of Industrial Organization, 19: 953-973.

[30] Ludema, Rodney D. and Ian Wooton (2000) Economic Geography and the Fiscal Effects of Regional Integration. Journal of International Economics, 52(2): 331-357.

[31] McFadden (1974) Conditional Logit Analysis of Qualitative Choice Behavior. In P. Zarembka (ed.) Frontiers in Econometrics, New York: Academic Press, 105-142.

[32] Ottaviano, Gianmarco I.P. and Tanguy van Ypersele (2005) Market Size and Tax Competition. Journal of International Economics, 67: 25-46.

[33] Papke, Leslie E. (1991) Interstate Business Tax Differentials and New Firm Location: Evidence from Panel Data. Journal of Public Economics, 45(1): 47-68.

[34] Silva, J.M.C. Santos and Silvana Tenreyro (2006) The Log of Gravity. Review of Economics and Statistics, 88(4): 641-658.

[35] Solé-Ollé, Albert and Jordi Jofre-Monseny (2007) Tax Differentials and Agglomeration Economies in Intraregional Firm Location. IEB Working Paper, \#2007/2, University of Barcelona.

[36] Sørensen, Peter B. (2004) Company Tax Reform in the European Union. International Tax and Public Finance, 11(1): 91-115.

[37] Strauss-Kahn, Vanessa and Xavier Vives (2005) Why and Where Do Headquarters Move? CEPR Discussion Paper \#5070.

[38] Wilson, John D. (1999) Theories of Tax Competition. National Tax Journal, 52(2): 269304.

[39] Winkelmann, Rainer (2000) Econometric Analysis of Count Data (3rd ed.), Springer.

[40] Wooldridge, Jeffrey M. (1999) Distribution-Free Estimation of some Nonlinear Panel Data Models. Journal of Econometrics, 90(1): 77-99. 


\section{Figure 1: Profit Tax Rates Across Swiss Cantons}

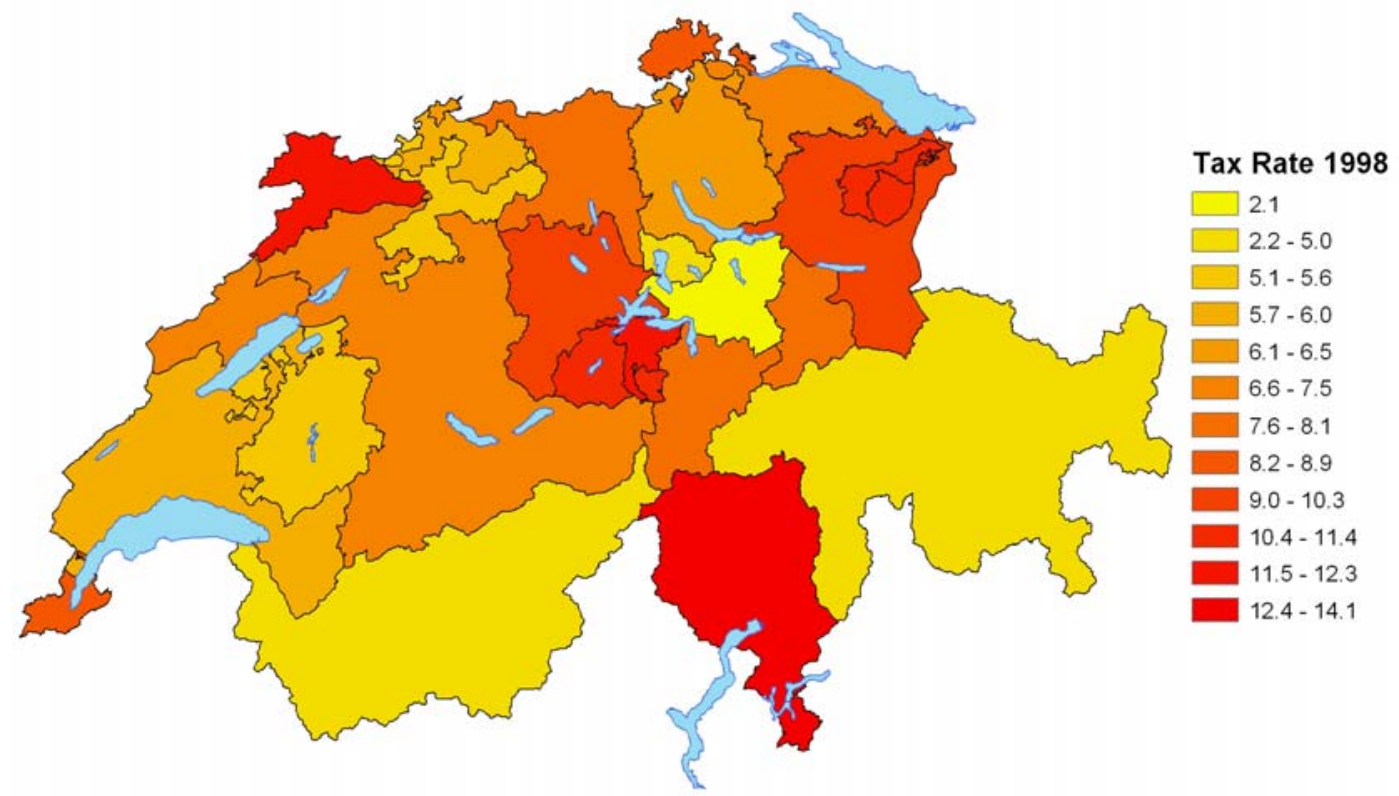

Notes: Cantonal and municipal statutory profit tax rates on a representative firm with $2 \%$ return on capital. Cantonal averages over all of the canton's sample municipalities in 1998. Blue areas are lakes.

Figure 2: Corporate Tax Burdens (Tax Index) Across Swiss Cantons

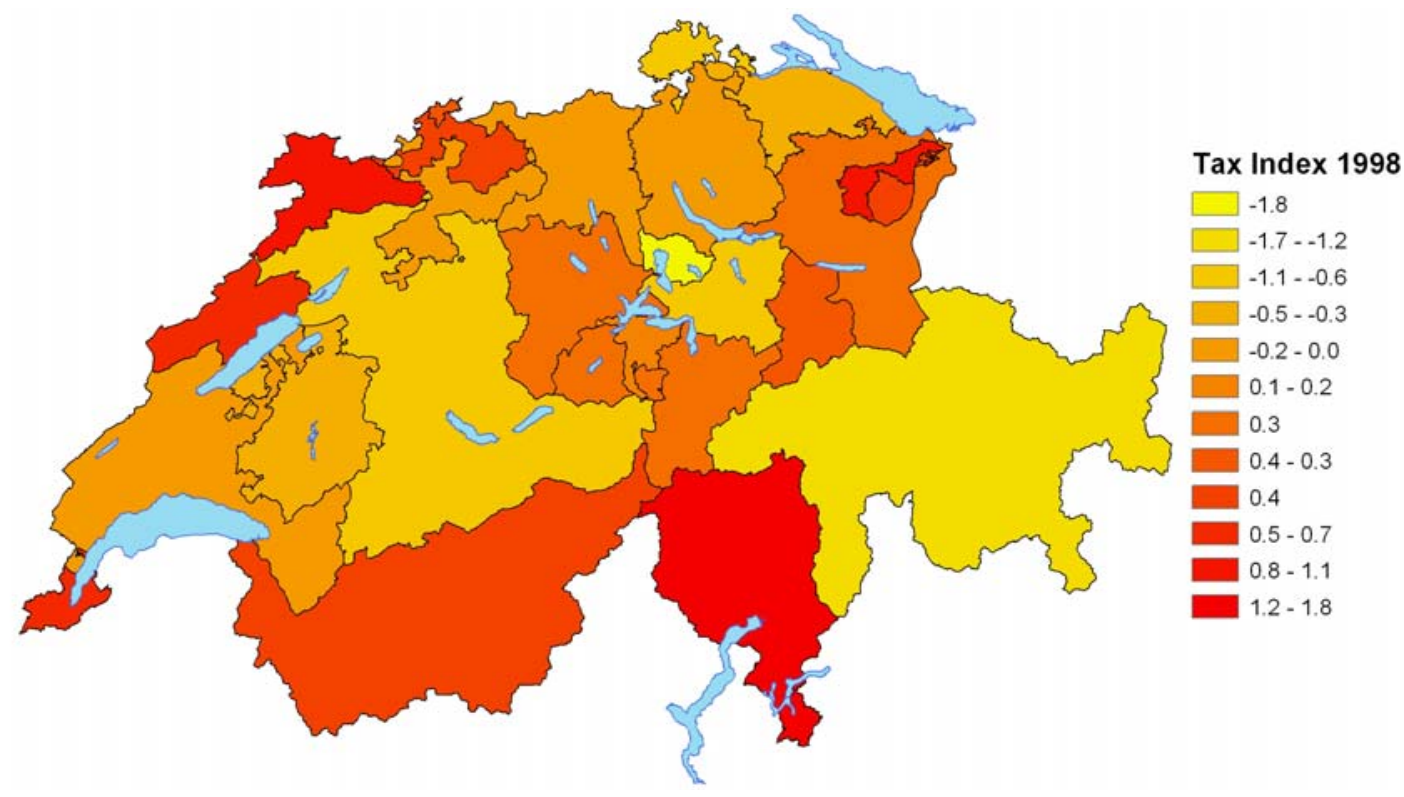

Notes: See data section for a description of the tax index. Cantonal averages over all of the canton's sample municipalities in 1998. Blue areas are lakes. 
Figure 3: Software Development and Consulting (Distribution of Firms in 1998) (EG index $=0.002)$

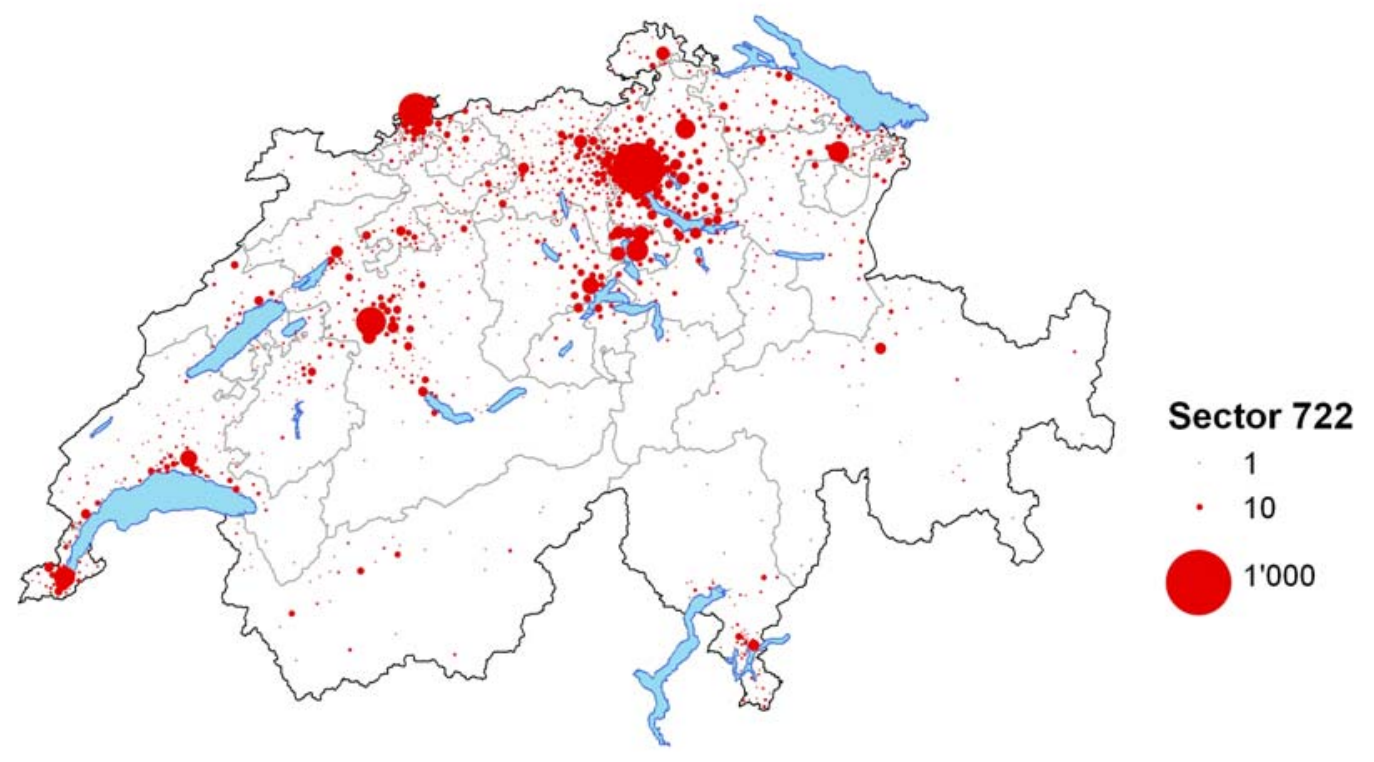

Figure 4: Software Development and Consulting (Taxes and New Firms, 1999-2000)

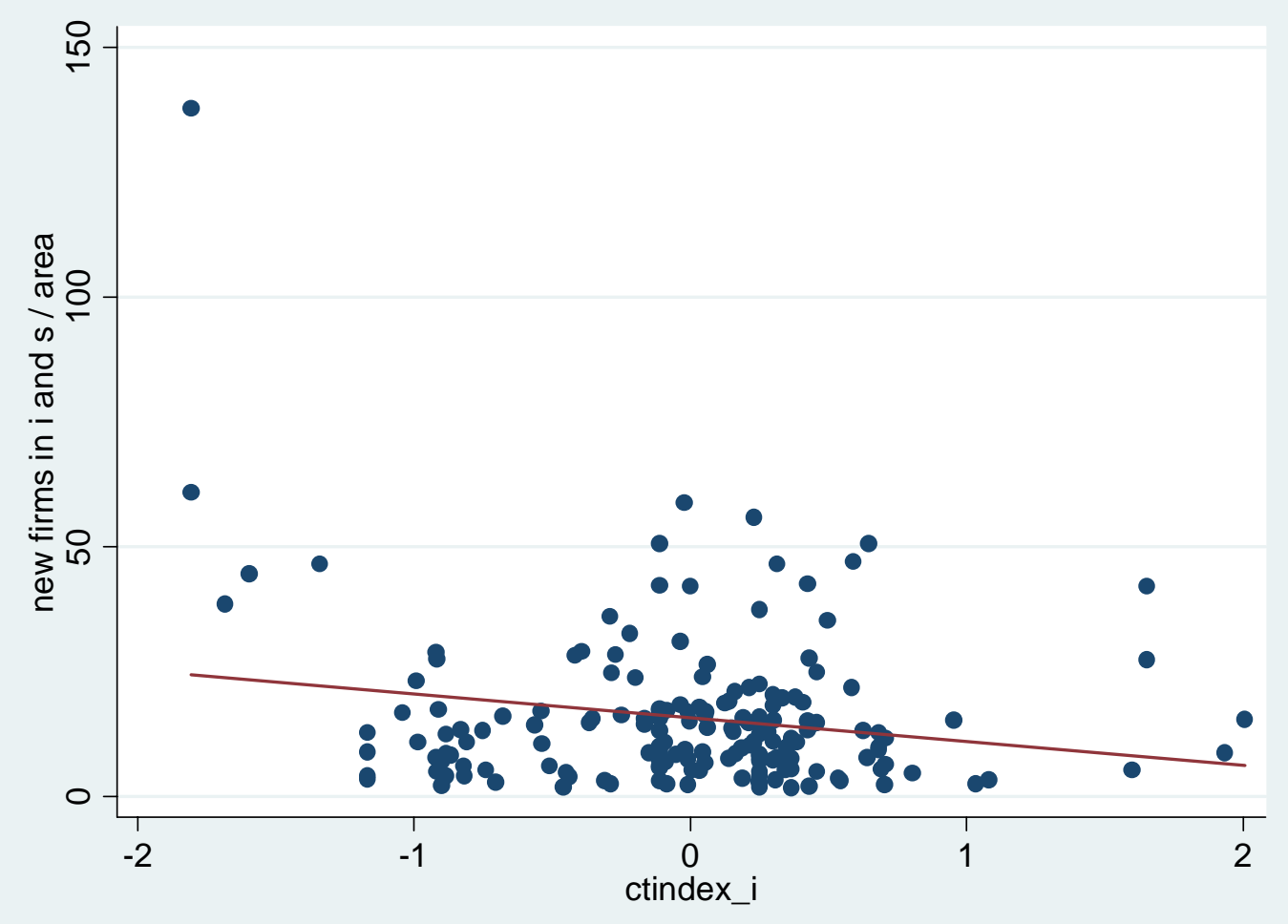

Notes: slope $=-4.80 ; t$-stat $=-2.68 ; R^{2}=0.039$ 
Figure 5: Production of Clothing (Distribution of Firms in 1998)

$(E G$ index $=0.008)$

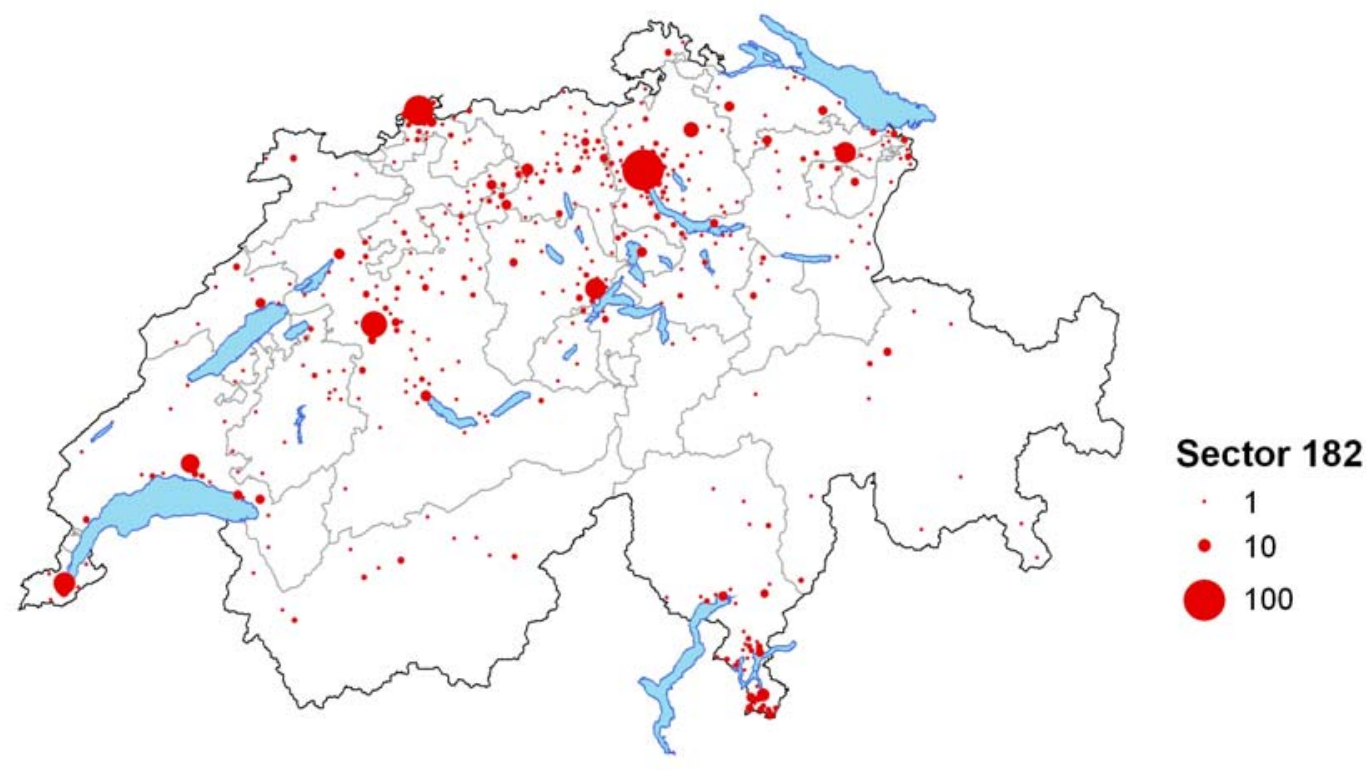

Figure 6: Production of Clothing (Taxes and New Firms, 1999-2000)

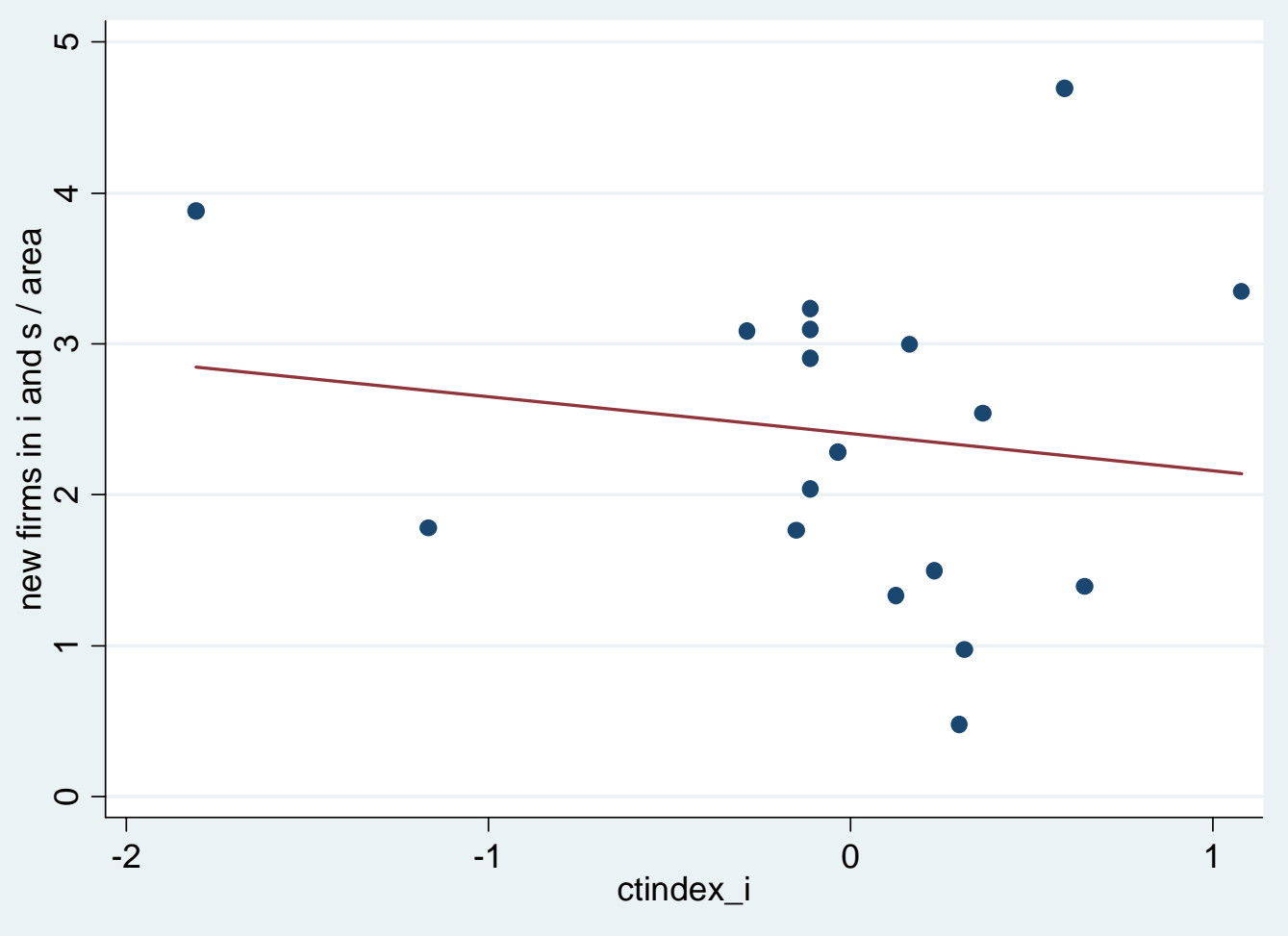

Notes: slope $=-0.24 ; t$-stat $=-0.58 ; R^{2}=0.021$ 
Figure 7: Brokerage and Wealth Management (Distribution of Firms in 1998)

(EG index $=0.079)$

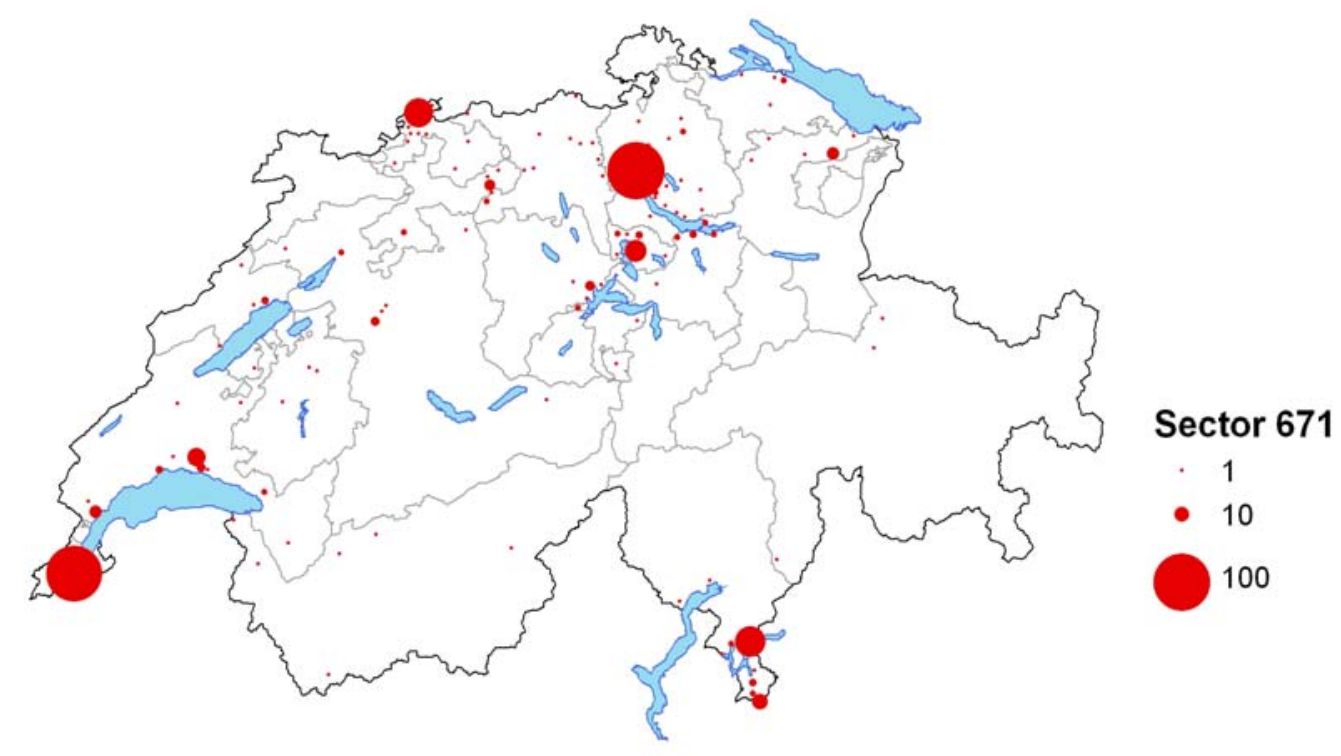

Figure 8: Brokerage and Wealth Management (Taxes and New Firms, 1999-2000)

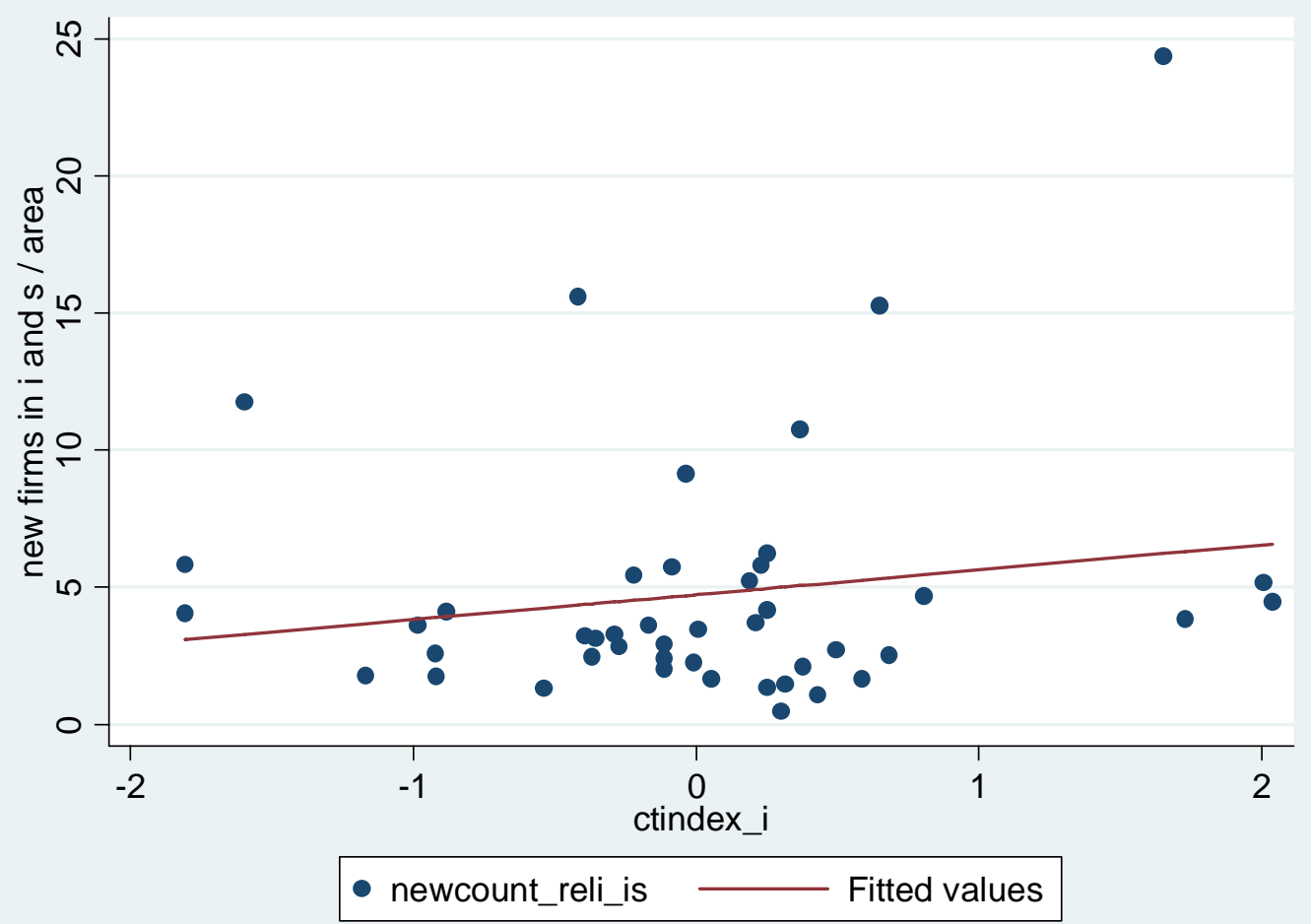

Notes: slope $=0.91 ; t$-stat $=1.14 ; R^{2}=0.030$ 
Figure 9: Tax-Versus-Agglomeration Effect

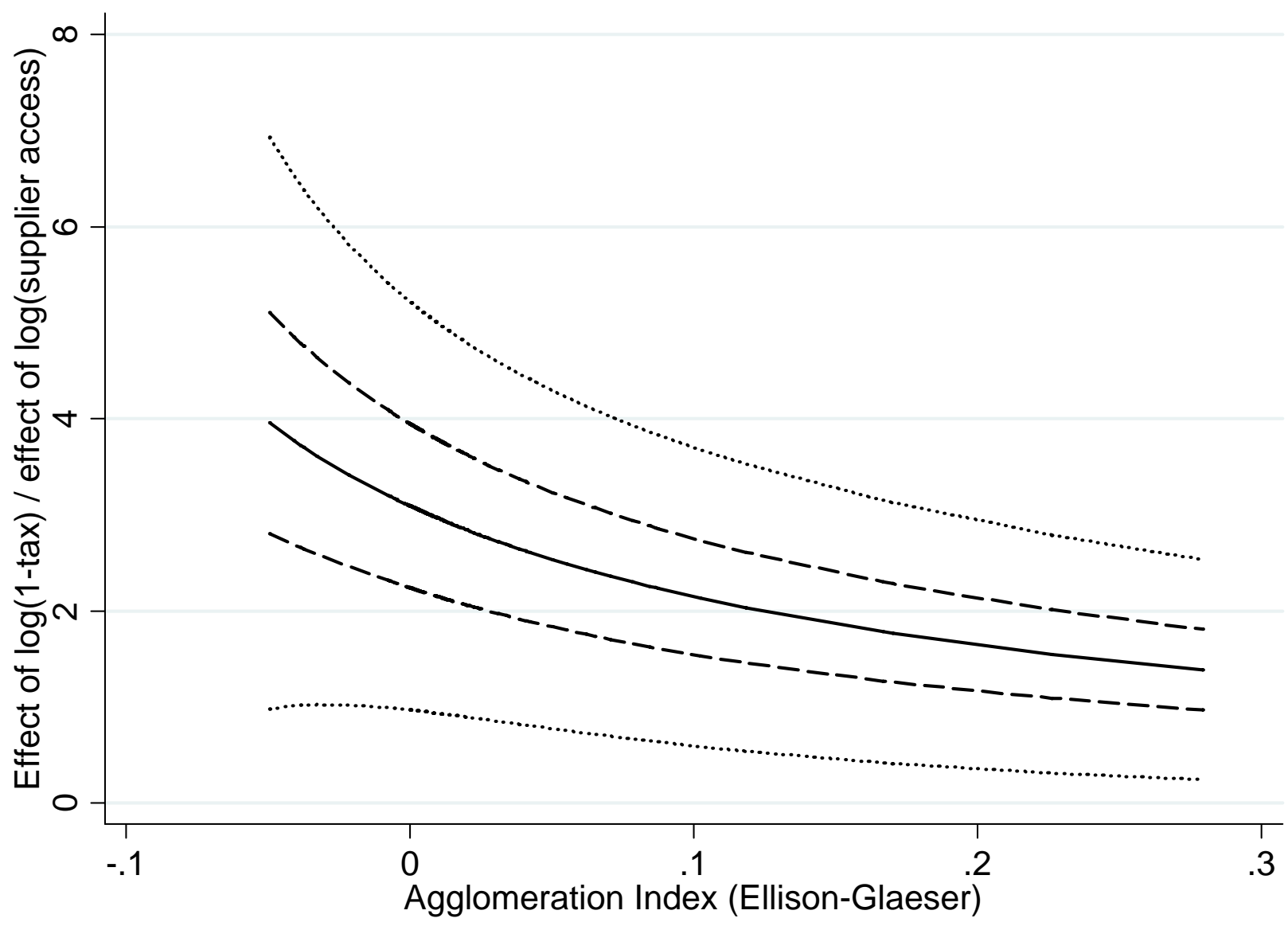

Notes: The graph illustrates the relative effect of taxes compared to the impact of supplier access as a function of the degree of agglomeration at the NACE three-digit sector level. The underlying computations are based on the coefficients in Table 5. 
Table 1: Descriptive Statistics

NACE 3-digit sector level, year 1998, 28,329 observations

\begin{tabular}{|c|c|c|c|c|c|c|c|}
\hline & Varies by & Mean & Std. Dev. & Min. & Mun./sector with min. & Max. & Mun./sector with max. \\
\hline New firms ${ }^{1}$ & mun., sector & 0.486 & 4.245 & 0 & several & 371 & $\begin{array}{c}\text { Zurich }(\mathrm{ZH}), \text { legal and } \\
\text { management consultancy } \\
\text { services }\end{array}$ \\
\hline Tax index & mun. & 0.000 & 0.641 & -1.81 & Zug (ZG) & 2.04 & Giubiasco $(\mathrm{TI})$ \\
\hline Corporate income tax ${ }^{2}$ & mun. & 10.681 & 2.167 & 5.45 & Baar $(Z G)$ & 18.39 & Giubiasco (TI) \\
\hline EG index & sector & 0.013 & 0.031 & -0.05 & $\begin{array}{l}\text { production of paints \& } \\
\text { printing inks }\end{array}$ & 0.23 & scheduled air travel \\
\hline Wage $^{3}$ & mun., sector & 6.000 & 0.771 & 3.38 & several & 7.77 & several \\
\hline Property price ${ }^{4}$ & mun. & 180.3 & 29.0 & 111.0 & Le Locle (NE) & 268.0 & Zollikon (ZH) \\
\hline Capital tax ${ }^{2}$ & mun. & 0.437 & 0.114 & 0.19 & Stans (NW) & 0.79 & Liestal (BL) \\
\hline Income tax ${ }^{2}$ & mun. & 6.704 & 1.442 & 2.96 & Baar (ZG) & 9.38 & Le Locle (NE) \\
\hline Public spending ${ }^{5}$ & mun. & 5.504 & 0.898 & 3.95 & Appenzell (Al) & 9.00 & Altdorf (UR) \\
\hline Sector proximity & mun., sector & 64.78 & 181.86 & 0.01 & $\begin{array}{l}\text { Chiasso }(\mathrm{TI}) \text {, } \\
\text { reproduction of } \\
\text { recording media }\end{array}$ & 6133.20 & Geneva (GE), banks \\
\hline Market potential $^{6}$ & mun. & 1.140 & 0.629 & 0.03 & Davos (GR) & 4.39 & Ecublens (VD) \\
\hline Distance to highway ${ }^{7}$ & mun. & 4.349 & 6.530 & 0.03 & Morges (VD) & 59.92 & St. Moritz (GR) \\
\hline Assisted municipalities & mun. & 0.249 & 0.432 & 0 & several & 1 & several \\
\hline Area & mun. & 422.8 & 454.9 & 73.0 & Massagno $(\mathrm{TI})$ & 5,346 & Zürich $(\mathrm{ZH})$ \\
\hline
\end{tabular}


Table 2: Baseline Model, Sector Fixed Effects

Dependent variable $=$ Number of new firms per municipality and sector

\begin{tabular}{|c|c|c|c|c|c|c|}
\hline \multirow[b]{2}{*}{ NACE sectors: } & \multicolumn{3}{|c|}{ Poisson } & \multicolumn{3}{|c|}{ Zero-Inflated Poisson } \\
\hline & 2 digit & 3 digit & 4 digit & 2 digit & 3 digit & 4 digit \\
\hline \multirow[t]{3}{*}{ Tax index } & -0.066 & -0.114 & -0.096 & -0.063 & -0.125 & -0.102 \\
\hline & $(0.017)^{\star \star \star}$ & $(0.012)^{\star \star \star}$ & $(0.011)^{\star \star \star}$ & $(0.018)^{\star \star \star}$ & $(0.013)^{\star \star \star}$ & $(0.012)^{\star \star \star}$ \\
\hline & $(0.07)$ & $(0.047)^{\star \star}$ & $(0.036)^{\star \star \star}$ & $(0.069)^{*}$ & $(0.050)^{\star \star}$ & $(0.038)^{* \star *}$ \\
\hline \multirow[t]{3}{*}{ Tax index * EG index } & 7.521 & 4.089 & 4.523 & 7.148 & 3.964 & 4.315 \\
\hline & $(1.354)^{\star \star \star}$ & $(0.766)^{\star \star \star}$ & $(0.603)^{\star \star \star}$ & $(1.485)^{\star \star \star}$ & $(0.818)^{\star \star \star}$ & $(0.621)^{\star \star \star}$ \\
\hline & $(4.882)$ & $(2.072)^{\star \star}$ & $(1.928)^{\star \star}$ & $(4.763)$ & $(3.047)$ & $(1.954)^{\star \star}$ \\
\hline \multirow[t]{3}{*}{ Wage } & -0.619 & -0.644 & -0.698 & -0.656 & -0.679 & -0.744 \\
\hline & $(0.025)^{\star \star \star}$ & $(0.022)^{\star \star \star}$ & $(0.022)^{\star \star \star}$ & $(0.027)^{\star \star \star}$ & $(0.023)^{\star \star \star}$ & $(0.023)^{\star \star \star}$ \\
\hline & $(0.065)^{\star \star \star}$ & $(0.078)^{* \star *}$ & $(0.070)^{* \star *}$ & $(0.090)^{* \star *}$ & $(0.070)^{\star \star \star *}$ & $(0.056)^{\star \star \star}$ \\
\hline \multirow[t]{3}{*}{ Wage * EG index } & 0.006 & 0.007 & 0.003 & 0.006 & 0.008 & 0.003 \\
\hline & $(0.002)^{\star \star \star}$ & $(0.001)^{\star \star \star}$ & $(0.001)^{\star \star \star}$ & $(0.002)^{\star \star}$ & $(0.001)^{\star \star \star}$ & $(0.001)^{\star \star \star}$ \\
\hline & $(0.005)$ & $(0.002)^{\star \star \star *}$ & $(0.002)$ & $(0.005)$ & $(0.002)^{\star \star \star}$ & $(0.002)^{\star \star}$ \\
\hline \multirow[t]{3}{*}{ Property price } & 0.671 & 0.500 & 0.437 & 0.450 & 0.255 & 0.175 \\
\hline & $(0.050)^{\star \star \star}$ & $(0.042)^{\star \star \star}$ & $(0.041)^{\star \star \star}$ & $(0.057)^{\star \star \star}$ & $(0.050)^{\star \star \star}$ & $(0.052)^{\star \star \star}$ \\
\hline & $(0.190)^{\star \star \star}$ & $(0.131)^{\star \star \star}$ & $(0.101)^{\star \star \star}$ & $(0.156)^{\star \star \star}$ & $(0.118)^{\star \star}$ & $(0.110)$ \\
\hline \multirow[t]{3}{*}{ Property price * EG index } & 0.156 & 0.116 & 0.103 & -0.011 & 0.033 & 0.033 \\
\hline & $(0.031)^{\star \star \star}$ & $(0.016)^{\star \star \star}$ & $(0.013)^{\star \star \star}$ & $(0.036)$ & $(0.019)^{\star}$ & $(0.015)^{\star \star}$ \\
\hline & $(0.102)$ & $(0.047)^{\star \star}$ & $(0.044)^{\star \star}$ & $(0.068)$ & $(0.036)$ & $(0.024)$ \\
\hline \multirow[t]{3}{*}{ Income tax } & -0.031 & -0.033 & -0.037 & -0.031 & -0.040 & -0.050 \\
\hline & $(0.005)^{\star \star \star}$ & $(0.005)^{\star \star \star}$ & $(0.005)^{\star \star \star}$ & $(0.005)^{\star \star \star}$ & $(0.006)^{\star \star \star}$ & $(0.006)^{\star \star \star}$ \\
\hline & $(0.015)^{\star \star}$ & $(0.011)^{\star \star *}$ & $(0.011)^{\star \star \star}$ & $(0.025)$ & $(0.019)^{\star \star}$ & $(0.017)^{\star \star \star}$ \\
\hline \multirow[t]{3}{*}{ Public expenditure } & 0.168 & 0.172 & 0.175 & 0.180 & 0.180 & 0.180 \\
\hline & $(0.009)^{\star \star \star}$ & $(0.009)^{\star \star \star}$ & $(0.009)^{\star \star \star}$ & $(0.009)^{\star \star \star}$ & $(0.010)^{\star \star \star}$ & $(0.011)^{\star \star \star}$ \\
\hline & $(0.014)^{\star \star \star}$ & $(0.010)^{* \star *}$ & $(0.012)^{\star \star \star}$ & $(0.033)^{* \star *}$ & $(0.026)^{\star \star \star}$ & $(0.024)^{\star \star \star}$ \\
\hline \multirow[t]{3}{*}{ Sector proximity } & 0.236 & 0.486 & 0.599 & 0.241 & 0.456 & 0.500 \\
\hline & $(0.006)^{\star \star \star}$ & $(0.012)^{\star \star \star}$ & $(0.015)^{\star \star \star}$ & $(0.006)^{\star \star \star}$ & $(0.013)^{\star \star \star}$ & $(0.017)^{\star \star \star}$ \\
\hline & $(0.047)^{\star \star \star}$ & $(0.048)^{\star \star *}$ & $(0.106)^{\star \star *}$ & $(0.035)^{* \star *}$ & $(0.072)^{\star \star \star}$ & $(0.093)^{\star \star \star}$ \\
\hline \multirow[t]{3}{*}{ Market potential } & 0.228 & 0.344 & 0.421 & 0.187 & 0.385 & 0.493 \\
\hline & $(0.014)^{\star \star \star}$ & $(0.012)^{\star \star \star}$ & $(0.012)^{\star \star \star}$ & $(0.016)^{\star \star \star}$ & $(0.015)^{\star \star \star}$ & $(0.014)^{\star \star \star}$ \\
\hline & $(0.102)^{\star \star}$ & $(0.041)^{* \star *}$ & $(0.031)^{* \star *}$ & $(0.058)^{* \star *}$ & $(0.051)^{\star \star \star}$ & $(0.042)^{\star \star \star}$ \\
\hline \multirow[t]{3}{*}{ Distance to highway } & -0.028 & -0.028 & -0.028 & -0.027 & -0.025 & -0.024 \\
\hline & $(0.002)^{\star \star \star}$ & $(0.002)^{\star \star \star}$ & $(0.002)^{\star \star \star}$ & $(0.002)^{\star \star \star}$ & 0.002 & $(0.002)^{\star \star \star}$ \\
\hline & $(0.005)^{\star \star \star *}$ & $(0.004)^{\star * \star \star}$ & $(0.003)^{\star \star \star *}$ & $(0.003)^{* \star *}$ & $(0.003)^{\star \star \star}$ & $(0.003)^{\star \star \star}$ \\
\hline \multirow[t]{3}{*}{ Assisted municipalities } & -0.179 & -0.202 & -0.223 & -0.198 & -0.222 & -0.264 \\
\hline & $(0.021)^{\star \star \star}$ & $(0.021)^{\star \star \star}$ & $(0.022)^{\star \star \star}$ & $(0.023)^{\star \star \star}$ & $(0.025)^{\star \star \star}$ & $(0.026)^{\star \star \star}$ \\
\hline & $(0.039)^{\star \star \star}$ & $(0.042)^{\star \star \star}$ & $(0.040)^{\star \star \star *}$ & $(0.070)^{\star \star \star *}$ & $(0.059)^{\star \star \star}$ & $(0.050)^{\star \star \star}$ \\
\hline \multirow[t]{3}{*}{ Area } & 0.646 & 0.654 & 0.661 & 0.629 & 0.609 & 0.584 \\
\hline & $(0.004)^{\star \star \star}$ & $(0.004)^{\star \star \star}$ & $(0.004)^{\star \star \star}$ & $(0.005)^{\star \star \star}$ & $(0.005)^{\star \star \star}$ & $(0.005)^{\star \star \star}$ \\
\hline & $(0.010)^{* \star *}$ & $(0.010)^{* \star * \star}$ & $(0.007)^{\star \star *}$ & $(0.017)^{* \star *}$ & $(0.013)^{\star \star \star}$ & $(0.012)^{* \star *}$ \\
\hline \multirow[t]{3}{*}{ Dummy for 2001} & -0.119 & -0.122 & -0.101 & -0.108 & -0.098 & -0.073 \\
\hline & $(0.013)^{\star \star \star}$ & $(0.013)^{\star \star \star}$ & $(0.013)^{\star \star \star}$ & $(0.013)^{\star \star \star}$ & $(0.014)^{\star \star \star}$ & $(0.014)^{\star \star \star}$ \\
\hline & $(0.043)^{\star \star \star}$ & $(0.029) * \star \star$ & $(0.030)^{* \star \star}$ & $(0.052)^{\star \star}$ & $(0.039)^{\star \star}$ & $(0.037)^{\star \star}$ \\
\hline Log likelihood & $-18,208$ & $-28,406$ & $-36,481$ & $-17,526$ & $-27,192$ & $-34,869$ \\
\hline No. of sectors & 41 & 133 & 242 & 41 & 133 & 242 \\
\hline No. of observations & 17,261 & 55,993 & 101,669 & 17,261 & 55,993 & 101,669 \\
\hline
\end{tabular}

Notes: ${ }^{\star} p<0.1,{ }^{\star \star} p<0.05,{ }^{\star \star \star} p<0.01$; standard errors in parentheses; robust standard errors in parentheses and italics. 
Table 3: Baseline Model, Sector and Location Fixed Effects

$$
\text { Dependent variable }=\text { Number of new firms per municipality and sector }
$$
Poisson Estimation

\begin{tabular}{|c|c|c|c|}
\hline NACE sectors: & 2 digit & 3 digit & 4 digit \\
\hline \multirow[t]{3}{*}{ Tax index * EG index } & 3.377 & 3.134 & 2.601 \\
\hline & $(1.036)^{\star \star \star}$ & $(0.640)^{\star \star \star}$ & $(0.483)^{\star \star \star}$ \\
\hline & $(2.451)$ & $(1.134)^{\star \star \star}$ & $(0.981)^{\star \star \star}$ \\
\hline \multirow[t]{3}{*}{ Wage } & 0.001 & 0.002 & -0.013 \\
\hline & 0.035 & 0.035 & $(0.035)^{\star}$ \\
\hline & $(0.126)$ & $(0.092)$ & $(0.071)$ \\
\hline \multirow[t]{3}{*}{ Wage * EG index } & -0.003 & 0.002 & 0.001 \\
\hline & 0.002 & $(0.001)^{\star}$ & $(0.001)^{\star}$ \\
\hline & $(0.005)$ & $(0.002)$ & $(0.001)$ \\
\hline \multirow[t]{3}{*}{ Property price * EG index } & 0.191 & 0.171 & 0.121 \\
\hline & $(0.031)^{\star \star \star}$ & $(0.017)^{\star \star \star}$ & $(0.013)^{\star \star \star}$ \\
\hline & $(0.108)^{\star}$ & $(0.055)^{\star \star \star}$ & $(0.055)^{* \star}$ \\
\hline \multirow[t]{3}{*}{ Sector proximity } & 0.099 & 0.228 & 0.538 \\
\hline & $(0.008)^{\star \star \star}$ & $(0.015)^{\star \star \star}$ & $(0.027)^{\star \star \star}$ \\
\hline & $(0.027)^{\star \star \star}$ & $(0.049)^{\star \star \star}$ & $(0.061)^{\star \star \star}$ \\
\hline \multirow[t]{3}{*}{ Dummy for 2001} & -0.133 & -0.138 & -0.137 \\
\hline & $(0.013)^{\star \star \star}$ & $(0.013)^{\star \star \star}$ & $(0.013)^{\star \star \star}$ \\
\hline & $(0.030)^{\star * \star}$ & $(0.028)^{\star \star \star}$ & $(0.028)^{\star \star \star}$ \\
\hline Log likelihood & $-12,829$ & $-22,988$ & $-30,805$ \\
\hline No. of sectors & 41 & 133 & 242 \\
\hline No. of observations & 17,261 & 55,993 & 101,669 \\
\hline
\end{tabular}


Table 4: Specific Model, Sector Fixed Effects, Statutory Tax Rates

Dependent variable $=$ number of new firms per municipality and sector

\begin{tabular}{|c|c|c|c|c|c|c|}
\hline \multirow[b]{2}{*}{ NACE sectors: } & \multicolumn{3}{|c|}{ Poisson } & \multicolumn{3}{|c|}{ Zero-Inflated Poisson } \\
\hline & 2 digit & 3 digit & 4 digit & 2 digit & 3 digit & 4 digit \\
\hline \multirow[t]{2}{*}{ Log $(1$ - corporate income tax $)$} & 1.539 & 1.468 & 1.314 & 1.427 & 1.587 & 1.437 \\
\hline & $(0.232)^{\star \star \star}$ & $(0.232)^{\star \star \star}$ & $(0.233)^{\star \star \star}$ & $(0.242)^{\star \star \star}$ & $(0.250)^{\star \star \star}$ & $(0.263)^{\star \star \star}$ \\
\hline \multirow[t]{3}{*}{ Log wage } & -3.516 & -3.520 & -3.594 & -3.665 & -3.565 & -3.636 \\
\hline & $(0.117)^{\star \star \star}$ & $(0.117)^{\star \star \star}$ & $(0.118)^{\star \star \star}$ & $(0.122)^{\star \star \star}$ & $(0.121)^{\star \star \star}$ & $(0.123)^{\star \star \star}$ \\
\hline & $(0.364)^{\star \star *}$ & $(0.307)^{\star \star \star}$ & $(0.283)^{\star \star *}$ & $(0.301)^{\star \star \star}$ & $(0.212)^{\star \star \star}$ & $(0.189)^{\star \star \star}$ \\
\hline Log property price & $(0.284)$ & $(0.212)$ & $(0.175)$ & (0.153) & $(0.129)$ & $(0.122)$ \\
\hline \multirow[t]{3}{*}{ Log $(1+$ capital tax $)$} & -0.189 & -0.141 & -0.092 & -0.160 & -0.110 & -0.127 \\
\hline & $(0.078)^{\star \star}$ & $(0.078)^{\star}$ & $(0.079)$ & $(0.082)^{\star}$ & -0.087 & -0.091 \\
\hline & $(0.102)^{*}$ & $(0.091)$ & (0.099) & $(0.166)$ & $(0.145)$ & $-(0.132)$ \\
\hline $\log (1+$ income tax $)$ & -1.133 & -1.129 & -1.135 & -1.162 & -1.157 & -1.151 \\
\hline \multirow[t]{3}{*}{ Log (sector proximity) * EG index } & 1.461 & 2.173 & 1.034 & 2.318 & 2.389 & 1.220 \\
\hline & $(0.542)^{\star \star \star}$ & $(0.277)^{\star \star \star}$ & $(0.195)^{\star \star \star}$ & $(0.585)^{\star \star \star}$ & $(0.284)^{\star \star \star}$ & $(0.197)^{\star \star \star}$ \\
\hline & $(1.881)$ & $(1.188)^{*}$ & $(0.908)$ & $(1.064)^{\star \star}$ & $(0.566)^{\star \star \star}$ & $(0.380)^{\star \star \star}$ \\
\hline \multirow[t]{3}{*}{ Log market potential } & 0.215 & 0.297 & 0.335 & 0.250 & 0.387 & 0.459 \\
\hline & $(0.027)^{\star \star \star}$ & $(0.025)^{\star \star \star}$ & $(0.023)^{\star \star \star}$ & $(0.028)^{\star \star \star}$ & $(0.027)^{\star \star \star}$ & $(0.027)^{\star \star \star}$ \\
\hline & $(0.098)^{\star \star}$ & $(0.062)^{\star \star \star}$ & $(0.048)^{\star \star \star}$ & $(0.059)^{\star \star \star}$ & $(0.044)^{\star \star \star}$ & $(0.040)^{\star \star \star}$ \\
\hline \multirow[t]{3}{*}{ Log area } & 1.134 & 1.132 & 1.136 & 1.119 & 1.097 & 1.080 \\
\hline & $(0.007)^{\star \star \star}$ & $(0.007)^{\star \star \star}$ & $(0.007)^{\star \star \star}$ & $(0.007)^{\star \star \star}$ & $(0.008)^{\star \star \star}$ & $(0.008)^{\star \star \star}$ \\
\hline & $(0.011)^{\star * \star}$ & $(0.011)^{\star \star \star}$ & $(0.011)^{\star * *}$ & $(0.015)^{\star * \star}$ & $(0.013)^{\star * *}$ & $(0.014)^{\star \star \star *}$ \\
\hline \multirow[t]{2}{*}{ Dummy for 2001} & -0.220 & -0.219 & -0.205 & -0.216 & -0.201 & -0.183 \\
\hline & $(0.013)^{\star \star \star}$ & $(0.013)^{\star \star \star}$ & $(0.013)^{\star \star \star}$ & $(0.014)^{\star \star \star}$ & $(0.014)^{\star \star \star}$ & $(0.015)^{\star \star \star}$ \\
\hline
\end{tabular}

Notes : ${ }^{*} \mathrm{p}<0.1,{ }^{\star \star} \mathrm{p}<0.05,{ }^{\star \star \star} \mathrm{p}<0.01$; standard errors in parentheses; robust standard errors in parentheses and italics. 
Table 5: Specific Model, Sector Fixed Effects, Sector-Level Coefficients, Statutory Tax Rates

Dependent variable $=$ number of new firms per municipality and sector

\begin{tabular}{|c|c|c|c|c|c|c|}
\hline \multirow[b]{2}{*}{ NACE sectors: } & \multicolumn{3}{|c|}{ Poisson } & \multicolumn{3}{|c|}{ Constrained Poisson } \\
\hline & 2 digit & 3 digit & 4 digit & 2 digit & 3 digit & 4 digit \\
\hline \multirow[t]{2}{*}{ Log (1 - corporate income tax) } & 1.451 & 1.388 & 1.272 & 0.730 & 0.650 & 0.503 \\
\hline & $(0.233)^{\star \star \star}$ & $(0.233)^{\star \star \star}$ & $(0.233)^{\star \star \star}$ & $(0.227)^{\star \star \star}$ & $(0.227)^{\star \star \star}$ & $(0.227)^{\star \star}$ \\
\hline \multirow[t]{3}{*}{$\log (1+$ capital tax $)$} & -0.127 & -0.081 & -0.024 & -0.242 & -0.196 & -0.140 \\
\hline & $(0.079)$ & $(0.079)$ & $(0.079)$ & $(0.077)^{\star \star \star}$ & $(0.077)^{\star \star}$ & $(0.078)^{\star}$ \\
\hline & $(0.086)$ & $(0.084)$ & $-(0.097)$ & $(0.071)^{\star \star \star}$ & $(0.079)^{\star \star}$ & $(0.101)$ \\
\hline $\log (1+$ income tax $)$ & $(0.115)^{\star \star \star}$ & $(0.078)^{\star \star \star}$ & $(0.070)^{\star \star \star}$ & $(0.151)^{\star \star \star}$ & $(0.060)^{\star \star \star}$ & $(0.053)^{\star \star *}$ \\
\hline \multirow[t]{3}{*}{ Log sector proximity } & 0.503 & 0.475 & 0.456 & 0.537 & 0.499 & 0.474 \\
\hline & $(0.013)^{\star \star \star}$ & $(0.011)^{\star \star \star}$ & $(0.009)^{\star \star \star}$ & $(0.013)^{\star \star \star}$ & $(0.010)^{\star \star \star}$ & $(0.009)^{\star \star \star}$ \\
\hline & $(0.047)^{\star \star \star}$ & $(0.031)^{\star \star \star}$ & $(0.024)^{\star \star \star}$ & $(0.063)^{\star \star \star}$ & $(0.038)^{\star \star \star}$ & $(0.026)^{\star \star \star}$ \\
\hline Log (sector proximity) * EG index & 0.128 & 1.975 & 0.827 & -0.022 & 1.856 & 0.794 \\
\hline \multirow[t]{3}{*}{ Dummy for 2001} & -0.207 & -0.210 & -0.196 & -0.221 & -0.222 & -0.208 \\
\hline & $(0.013)^{\star \star \star}$ & $(0.013)^{\star \star \star}$ & $(0.013)^{\star \star \star}$ & $(0.013)^{\star \star \star}$ & $(0.013)^{\star \star \star}$ & $(0.013)^{\star \star \star}$ \\
\hline & $(0.033)^{\star \star \star}$ & $(0.031)^{\star \star \star}$ & $(0.028)^{\star \star \star}$ & $(0.040)^{\star \star \star}$ & $(0.028)^{\star \star \star}$ & $(0.028)^{\star \star \star}$ \\
\hline Log likelihood & $-13,707$ & $-23,592$ & $-31,272$ & $-13,891$ & $-23,770$ & $-31,459$ \\
\hline Chi2-stat Sector dummies * Wage & 551.66 & 15.86 & 32.81 & 687.76 & 16.54 & 29.31 \\
\hline Chi2-stat Sector dummies * Property price & $1,203.53$ & 52.95 & 108.34 & 764.83 & 54.29 & 110.44 \\
\hline Chi2-stat Sector dummies * Market potential & 871.07 & 27.56 & 18.63 & $1,137.80$ & 25.80 & 17.27 \\
\hline No. of sectors & 41 & 133 & 242 & 41 & 133 & 242 \\
\hline No. of observations & 17,261 & 55,993 & 101,669 & 17,261 & 55,993 & 101,669 \\
\hline
\end{tabular}

Table 6: Specific Model, Sector and Location Fixed Effects

Dependent variable $=$ number of new firms per municipality and sector

Poisson estimation

\begin{tabular}{|c|c|c|c|}
\hline NACE sectors: & 2 digit & 3 digit & 4 digit \\
\hline \multirow[t]{3}{*}{ Log wage } & -1.004 & -0.971 & -0.873 \\
\hline & $(0.212)^{\star \star \star}$ & $(0.214)^{\star \star \star}$ & $(0.213)^{\star \star \star}$ \\
\hline & $(0.523)^{*}$ & $(0.396)^{\star \star}$ & $(0.327)^{\star \star \star}$ \\
\hline \multirow[t]{3}{*}{ Log sector proximity } & 0.560 & 0.476 & 0.452 \\
\hline & $(0.015)^{\star \star \star}$ & $(0.012)^{\star \star \star}$ & $(0.010)^{\star \star \star}$ \\
\hline & $(0.052)^{\star \star \star}$ & $(0.028)^{\star \star \star}$ & $(0.023)^{\star \star \star}$ \\
\hline \multirow[t]{3}{*}{ Log (sector proximity) * EG index } & 0.772 & 1.997 & 0.885 \\
\hline & 0.538 & $(0.280)^{\star \star \star}$ & $(0.191)^{\star \star \star}$ \\
\hline & $(1.060)$ & $(0.751)^{\star \star \star}$ & $(0.664)$ \\
\hline \multirow[t]{3}{*}{ Dummy for 2001} & -0.200 & -0.196 & -0.185 \\
\hline & $(0.013)^{\star \star \star}$ & $(0.013)^{\star \star \star}$ & $(0.013)^{\star \star \star}$ \\
\hline & $(0.041)^{\star \star \star}$ & $(0.032)^{\star \star \star}$ & $(0.030)^{\star \star \star}$ \\
\hline Log likelihood & $-12,267$ & $-22,224$ & $-29,918$ \\
\hline No. of sectors & 41 & 133 & 242 \\
\hline No. of observations & 17,261 & 55,993 & 101,669 \\
\hline
\end{tabular}

Notes: * $p<0.1,{ }^{\star \star} p<0.05,{ }^{* \star \star} p<0.01$; standard errors in parentheses; robust standard errors in parentheses and italics. 
Table 7: Specific Model, Sector Fixed Effects, Tax Index

Dependent variable $=$ number of new firms per municipality and sector

\begin{tabular}{|c|c|c|c|c|c|c|}
\hline \multirow[b]{2}{*}{ NACE sectors: } & \multicolumn{3}{|c|}{ Poisson } & \multicolumn{3}{|c|}{ Zero-Inflated Poisson } \\
\hline & 2 digit & 3 digit & 4 digit & 2 digit & 3 digit & 4 digit \\
\hline \multirow[t]{2}{*}{ Tax index } & -0.102 & -0.096 & -0.087 & -0.097 & -0.101 & -0.096 \\
\hline & $(0.001)^{\star \star \star}$ & $(0.009)^{\star \star \star}$ & $(0.009)^{\star \star \star}$ & $(0.010)^{\star \star \star}$ & $(0.010)^{\star \star \star}$ & $(0.010)^{\star \star \star}$ \\
\hline \multirow[t]{3}{*}{ Log wage } & -3.294 & -3.291 & -3.362 & -3.424 & -3.322 & -3.412 \\
\hline & $(0.117)^{\star \star \star}$ & $(0.117)^{\star \star \star}$ & $(0.118)^{\star \star \star}$ & $(0.121)^{\star \star \star}$ & $(0.121)^{\star \star \star}$ & $(0.122)^{\star \star \star}$ \\
\hline & $(0.366)^{\star \star \star}$ & $(0.304)^{\star \star \star}$ & $(0.284)^{\star \star \star}$ & $(0.302)^{\star \star \star}$ & $(0.216)^{\star \star \star}$ & $(0.190)^{\star \star \star}$ \\
\hline Log property price & $(0.270)$ & $(0.200)$ & $(0.166)$ & $(0.151)$ & $(0.131)$ & $(0.126)^{\star \star}$ \\
\hline \multirow[t]{3}{*}{ Log income tax } & -0.945 & -0.940 & -0.945 & -0.966 & -0.947 & -0.946 \\
\hline & $(0.029)^{\star \star \star}$ & $(0.029)^{\star \star \star}$ & $(0.029)^{\star \star \star}$ & $(0.030)^{\star \star \star}$ & $(0.031)^{\star \star \star}$ & $(0.033)^{\star \star \star}$ \\
\hline & $(0.080)^{\star \star \star}$ & $(0.054)^{\star \star \star}$ & $(0.055)^{\star \star \star}$ & $(0.086)^{\star \star \star}$ & $(0.070)^{\star \star \star}$ & $(0.062)^{\star \star \star}$ \\
\hline Log sector proximity & 0.577 & 0.518 & 0.493 & 0.572 & 0.503 & 0.471 \\
\hline Log (sector proximity) * EG index & $(1.876)$ & $(1.174)^{\star}$ & $(0.900)$ & $(1.051)^{\star \star}$ & $(0.559)^{\star \star \star}$ & $(0.378)^{\star \star \star}$ \\
\hline \multirow[t]{3}{*}{ Log market potential } & 0.243 & 0.327 & 0.366 & 0.278 & 0.420 & 0.495 \\
\hline & $(0.027)^{\star \star \star}$ & $(0.025)^{\star \star \star}$ & $(0.024)^{\star \star \star}$ & $(0.028)^{\star \star \star}$ & $(0.027)^{\star \star \star}$ & $(0.027)^{\star \star \star}$ \\
\hline & $(0.103)^{\star \star}$ & $(0.065)^{\star \star \star}$ & $(0.049)^{\star \star \star}$ & $(0.058)^{\star \star \star}$ & $(0.044)^{\star \star \star}$ & $(0.040)^{\star \star *}$ \\
\hline \multirow[t]{3}{*}{ Log area } & 1.142 & 1.139 & 1.142 & 1.126 & 1.105 & 1.088 \\
\hline & $(0.007)^{\star \star \star}$ & $(0.007)^{\star \star \star}$ & $(0.007)^{\star \star \star}$ & $(0.007)^{\star \star \star}$ & $(0.008)^{\star \star \star}$ & $(0.008)^{\star \star \star}$ \\
\hline & $(0.011)^{\star \star \star}$ & $(0.011)^{\star \star \star}$ & $(0.012)^{\star \star \star}$ & $(0.015)^{\star \star \star}$ & $(0.013)^{\star \star \star}$ & $(0.013)^{\star \star \star}$ \\
\hline \multirow[t]{3}{*}{ Dummy for 2001} & -0.214 & -0.215 & -0.202 & -0.211 & -0.199 & -0.180 \\
\hline & $(0.013)^{\star \star \star}$ & $(0.013)^{\star \star \star}$ & $(0.013)^{\star \star \star}$ & $(0.013)^{\star \star \star}$ & $(0.014)^{\star \star \star}$ & $(0.014)^{\star \star \star}$ \\
\hline & $(0.037)^{\star \star \star}$ & $(0.033)^{\star \star \star}$ & $(0.031)^{\star \star \star}$ & $(0.032)^{\star \star \star}$ & $(0.026)^{\star \star \star}$ & $(0.025)^{\star \star \star}$ \\
\hline Log likelihood & $-13,844$ & $-23,736$ & $-31,431$ & $-13,914$ & $-23,963$ & $-31,827$ \\
\hline No. of sectors & 41 & 133 & 242 & 41 & 133 & 242 \\
\hline
\end{tabular}

Notes : ${ }^{*} p<0.1,{ }^{* \star} p<0.05,{ }^{\star \star \star} p<0.01$; standard errors in parentheses; robust standard errors in parentheses and italics. 